\title{
A preliminary assessment of the extent and potential impacts of alien plant invasions in the Serengeti-Mara ecosystem, East Africa
}

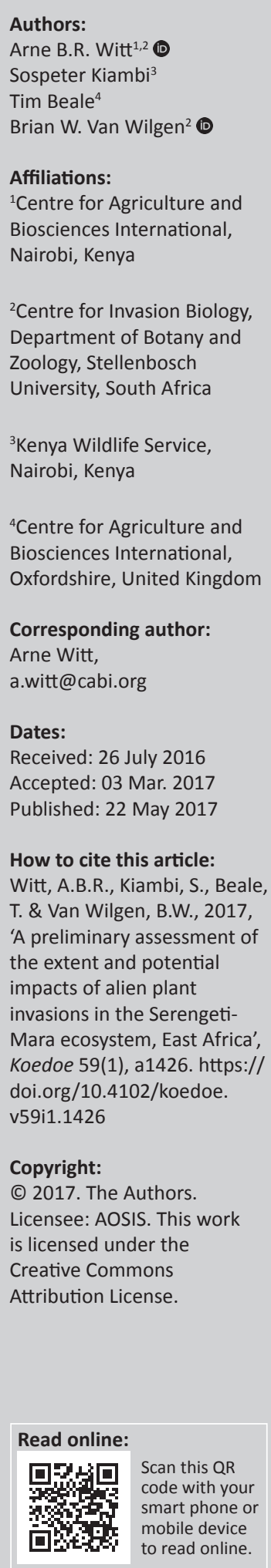

This article provides a preliminary list of alien plant species in the Serengeti-Mara ecosystem in East Africa. The list is based on broad-scale roadside surveys in the area and is supplemented by more detailed surveys of tourist facilities in the Masai-Mara National Reserve and adjoining conservancies. We encountered 245 alien plant species; significantly more than previous studies, of which $62(25 \%)$ were considered to have established self-perpetuating populations in areas away from human habitation. These included species which had either been intentionally or accidentally introduced. Of the 245 alien plants, 212 (including four species considered to be native to the region) were intentionally introduced into gardens in the National Reserve and 51 (24\%) had established naturalised populations within the boundaries of these tourism facilities. Of the 51 naturalised species, 23 (11\% of the 212 alien species) were recorded as being invasive within the ecosystem, outside of lodges and away from other human habitation. Currently, the Serengeti-Mara ecosystem is relatively free of widespread and abundant invasive alien plants, with a few exceptions, but there are extensive populations outside of the ecosystem, particularly to the west, from where they could spread. We address the potential impacts of six species that we consider to pose the highest risks (Parthenium hysterophorus, Opuntia stricta, Tithonia diversifolia, Lantana camara, Chromolaena odorata and Prosopis juliflora). Although invasive alien plants pose substantial threats to the integrity of the ecosystem, this has not yet been widely recognised. We predict that in the absence of efforts to contain, or reverse the spread of invasive alien plants, the condition of rangelands will deteriorate, with severe negative impacts on migrating large mammals, especially wildebeest, zebra and gazelles. This will, in turn, have a substantial negative impact on tourism, which is a major economic activity in the area.

Conservation implications: Invasive alien plants pose significant threats to the integrity of the Serengeti-Mara ecosystem and steps will need to be taken to prevent these impacts. The most important of these would be the removal of alien species from tourist facilities, especially those which are known to be naturalised or invasive, the introduction of control programmes aimed at eliminating outlier invasive plant populations to slow down the spread, and the widespread use of biological control wherever possible.

\section{Introduction}

The establishment and management of a network of protected areas is a key component of global strategies to protect biodiversity and to conserve a representative sample of the Earth's ecosystems. Proclamation of protected areas is in itself no guarantee that the ecosystems therein will not become degraded, as they face a host of threats, including chronic shortages of management funds, legal and illegal resource use, climate change, pollution and invasion by alien species. Ongoing active management will therefore be needed to address these threats. Invasive alien species can pose significant threats to protected area ecosystems worldwide (Foxcroft et al. 2013a), and one report (De Poorter 2007) identified 487 protected areas where invasive alien species were recorded as a threat. In Africa (with the notable exception of South Africa), very little is known about invasive alien species across the continent's protected areas (Foxcroft, Witt \& Lotter 2013b). A lack of information on the extent of these invasions, and the problems that they cause, ultimately translates into a failure to adequately provide for their management. As a starting point, therefore, it would be important to record the extent of the threats posed by invasive alien species to individual protected areas and to assess the options for achieving effective control (Van Wilgen et al. 2016).

In this article, we report on the findings of surveys of invasive alien plants in the Serengeti-Mara ecosystem in East Africa. Prior to our survey, the only available information on alien plants in the 
area was from Henderson (2002) who found 41 'problem' plants in the Ngorongoro Crater, 8 of which were considered to be native; a report by Bukombe et al. (2012) who recorded 13 alien plant species in the Serengeti National Park, including two species, Senna didymobotrya (Fresen.) H.S. Irwin \& Barneby (Fabaceae) and Ricinus communis L. (Euphorbiaceae), which are often considered to be native; and a report by Clark, Lotter and Runyoro (2010) who listed 147 invasive alien and indigenous 'weedy' species in the Ngorongoro Conservation Area. Our surveys subsequently revealed that many of the alien species listed by Clark et al. (2010) are not invasive. Here, we provide an updated list of the introduced, naturalised and invasive alien plant species present. We then focus on six taxa that are expected to generate the largest impacts and review the degree to which they may be expected to impact the integrity of the SerengetiMara ecosystem. We also make recommendations regarding the management interventions that would be required to prevent or reduce these impacts.

\section{Methods}

\section{Study site}

The Serengeti-Mara ecosystem is a trans-border area that covers $\pm 100000 \mathrm{~km}^{2}$ in the northwest of Tanzania and southwest of Kenya (Figure 1). The core conservation areas consist of the Masai-Mara National Reserve in Kenya which covers $\pm 1500 \mathrm{~km}^{2}$, while the Serengeti National Park in Tanzania covers $14750 \mathrm{~km}^{2}$. Both of these protected areas are surrounded by buffer zones such as inner and outer group ranches or conservancies in Kenya and the Ngorongoro Conservation Area, Loliondo Game Controlled Area and the Maswa, Grumeti and Ikorongo Game Reserves in Tanzania.

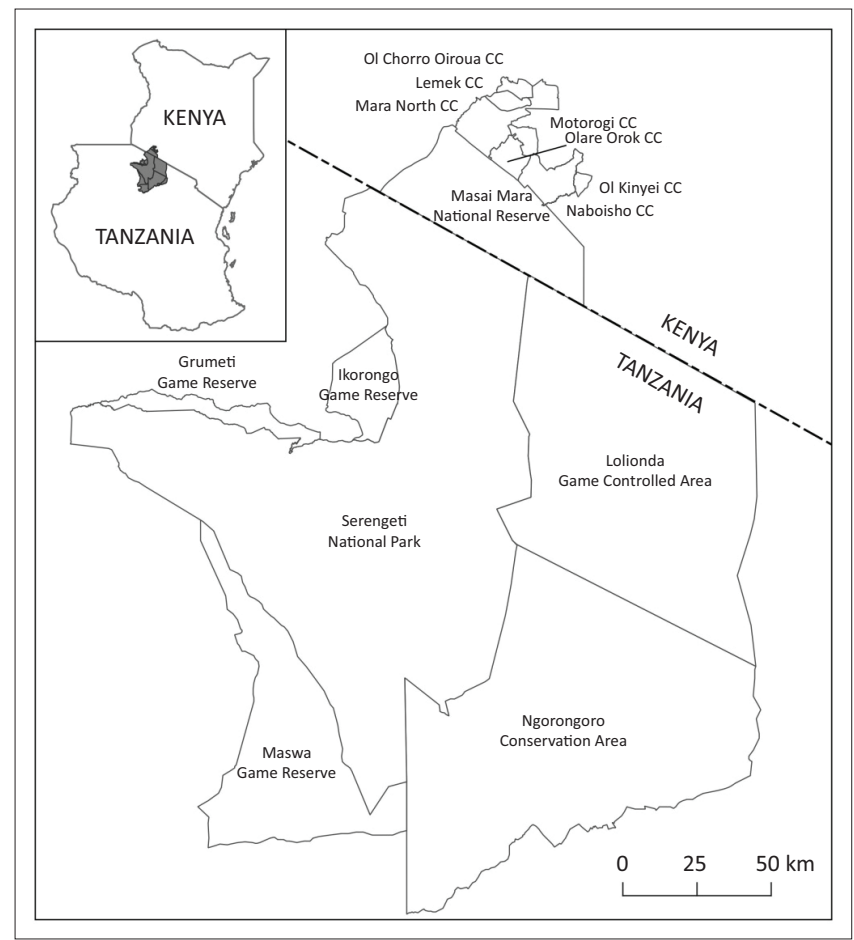

FIGURE 1: Location of the Masai-Mara National Reserve, the Serengeti Nationa Park, and surrounding protected areas in East Africa.
The area has varied vegetation and topography, including savanna, grassland, riverine forests, inselbergs (characteristic rock outcrops which rise suddenly above a plain) and wetlands. The mean annual rainfall is around $1000 \mathrm{~mm}$, ranging from $508 \mathrm{~mm}$ on the plains to $1200 \mathrm{~mm}$ near Lake Victoria in the west, with a short rainy season in October and November and a longer rainy season from March to May. The ecosystem is well known for the migration of 2 million animals (mainly wildebeest, zebras and gazelles), which range between the Serengeti National Park and surrounding conservation areas and the Masai-Mara National Reserve and the adjoining conservancies, and the area is an important tourist destination. The area has a relatively large number of tourist roads and tracks, especially in the Masai-Mara National Reserve, and several lodges have been built, starting in the 1960s; these lodges and other tourist facilities, such as camping sites, can accommodate thousands of tourists, and many more staff and community members reside permanently within the ecosystem.

\section{Species surveys}

Species surveys were undertaken in the Serengeti-Mara ecosystem during or just after the rains, in order to facilitate plant identification, because actively growing and flowering plants are easier to identify. An initial series of field surveys was carried out in the Masai-Mara National Reserve between 04 and 11 April 2011. During this time, we drove along most of the roads and some of the jeep tracks in an area known as the 'Mara Triangle', the National Reserve Central Plains, the National Reserve East and Ol Derikesi and conservancies to the north (Mara North, Lemek, Ol Choro, Enonkishu) and along the periphery of conservancies to the east (Isaaten and Siana) (Figure 2), with one observer recording the species seen, its status and approximate location. Coordinates, at or within $1 \mathrm{~km}$, of each locality where an alien species was found to be present or naturalised, or invasive and spreading (as defined by Pyšek et al. 2004), were recorded using a hand-held global positioning system (GPS) receiver. The methodology used was similar to that described by Henderson (2007) and Rejmánek et al. (2017). Where we could not immediately identify a species, herbarium specimens were collected or photographs taken for later identification by taxonomists. In August 2016, we undertook a further road survey to record the extent of Parthenium hysterophorus L. (Asteraceae) (a species that is currently spreading rapidly, but that is also actively being managed in the 'Mara Triangle') to assess both the degree of spread between 2011 and 2016 and the effectiveness of management interventions.

Similar vehicle-based observations were undertaken during two trips en transit through the Serengeti National Park and Ngorongoro Crater in 2012. In addition, we conducted vehicle-based surveys in land adjacent to the protected areas, especially to the west of the Serengeti National Park, where small-scale farming and pastoralism are the main land-use practices. Finally, we consolidated our list with those of Bukombe et al. (2012), Clark et al. (2010) and Henderson (2002), based on the surveys they undertook 

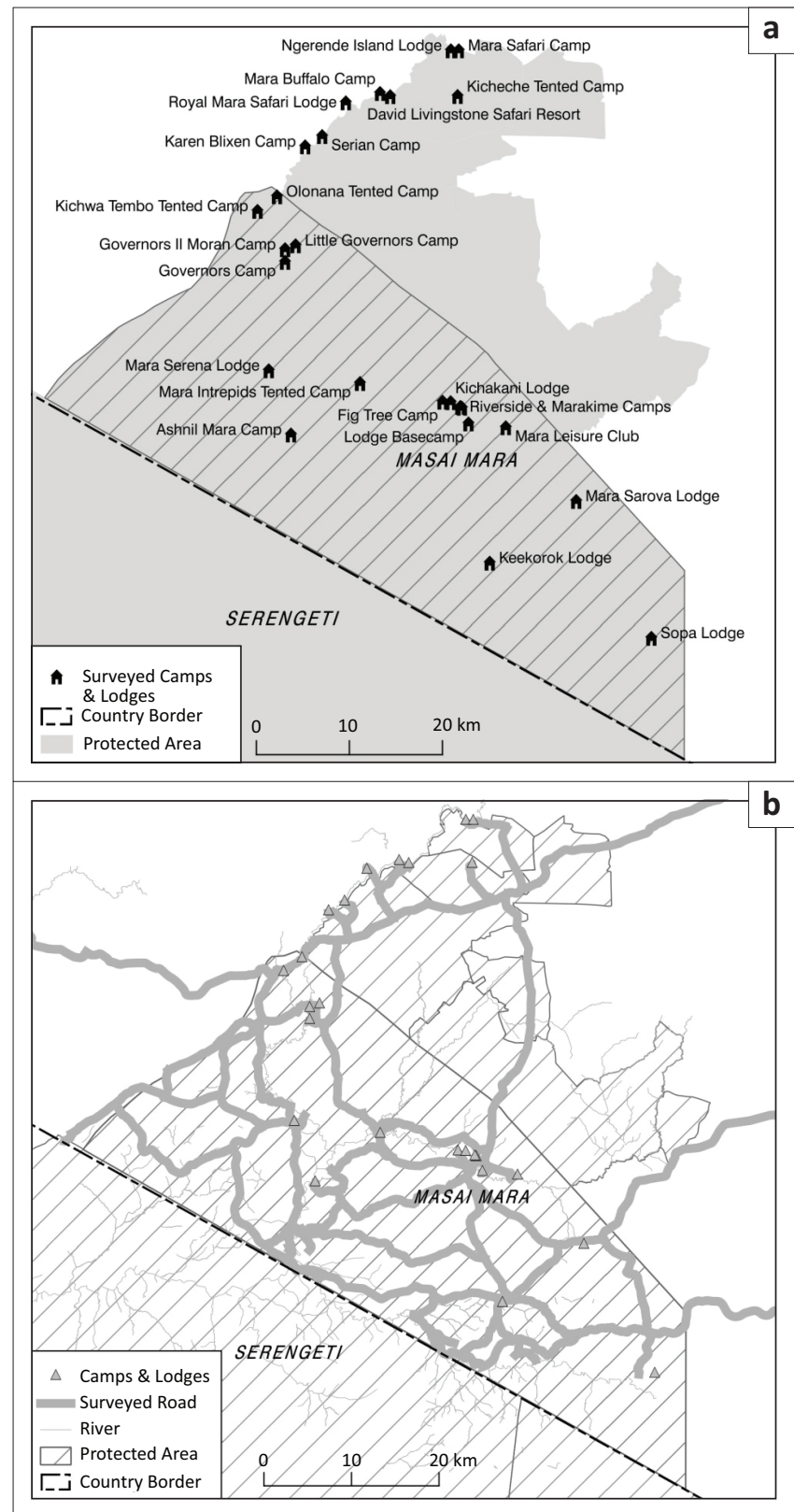

FIGURE 2: (a) Location of tourist nodes (lodges and other accommodation) in the Masai-Mara National Reserve and adjacent conservation areas that were surveyed for the occurrence of alien plant species and (b) roads in the area that were surveyed for the occurrence of alien plant species.

in the Ngorongoro Conservation Area and the Serengeti National Park.

\section{Tourism facilities as pathways of alien plant introductions}

Tourist facilities in protected areas can be an important source of invasive alien species. For example, Foxcroft, Richardson and Wilson (2008) surveyed 36 tourist camps and staff villages in the Kruger National Park, South Africa, and identified 258 alien plant species, several of which subsequently became important invaders of the surrounding ecosystem. We therefore surveyed the grounds of 24 tourist facilities (lodges or other accommodation sites, which often included relatively large, fenced grounds covered by natural vegetation) in the Masai-Mara National Reserve (Figure 2).
We noted all alien plant species present, and recorded whether the species had established naturalised populations within the tourism facilities and whether they had become invasive. Species were regarded as naturalised if they were considered to have been reproducing consistently, sustaining populations over many life cycles without direct intervention by humans (Richardson et al. 2000). Species were recorded as invasive if they were found to be spreading beyond the fences or outside of the tourism facilities or other human habitation.

\section{Evidence of impact of selected important species}

Although many alien species have established in the Serengeti-Mara ecosystem, a relatively small number poses disproportionate threats, as they spread rapidly, have the potential to invade large areas and can generate large impacts. According to Clark et al. (2010), it has been suggested that Acacia mearnsii De Wild, Leucaena leucocephala (Lam.) de Wit (Fabaceae), Caesalpinia decapetala (Roth) Alston (Fabaceae), Parkinsonia aculeata L. (Fabaceae), Melia azedarach L. (Meliaceae), Jacaranda mimosifolia D. Don (Bignoniaceae), Eucalyptus spp. (Myrtaceae), Lantana camara (L.) (Verbenaceae), Datura stramonium L. (Solanaceae), Lonicera japonica Thunb. (Caprifoliaceae) and Azolla filiculoides Lam. (possibly Azolla cristata Kaulf.) (Salviniaceae) pose the biggest threat to the Ngorongoro Conservation Area. However, we are of the opinion that of these 11 species, only L. camara and five others, not listed by any previous studies, pose an even bigger threat to the whole ecosystem based on their recorded impacts elsewhere in the region or on the continent and their current and potential distribution in the region, especially in the SerengetiMara ecosystem (Illori et al. 2010; Maundu et al. 2009; McConnachie et al. 2011; Shackleton et al. 2017; Shackleton et al. in press). All of these are known to be aggressively invasive and have the potential to substantially reduce the ability of rangelands to support grazing mammals, and several have other impacts, being allelopathic or toxic, or having an ability to affect the health of livestock or wildlife. The species were:

- Chromolaena odorata (L.) R.M. King \& H.Rob. (Asteraceae), a shrub from Central America

- Lantana camara, a shrub from Central and South America

- Opuntia stricta (Haw.) Haw. (Cactaceae), a spinescent stem succulent from Central America

- Parthenium hysterophorus L. (Asteraceae), an annual herb from tropical America

- Prosopis species and hybrids (Fabaceae), trees and shrubs from North, South and Central America

- Tithonia diversifolia (Hemsl.) A. Gray (Asteraceae), a shrub from Central America.

For each species, we located published accounts on the nature and extent of impacts associated with the species, and summarised this information in brief accounts intended to illustrate the potential of the species to impact on the conservation value of the Serengeti-Mara ecosystem. 


\section{Results}

\section{Species surveys}

During our roadside surveys, we encountered 62 alien plant species that had established adventive populations in the Serengeti-Mara ecosystem (Table 1). These included ruderal weeds such as Bidens pilosa L. (Asteraceae), Alternanthera pungens Kunth (Amaranthaceae), Gomphrena celosioides Mart (Amaranthaceae), Cirsium vulgare (Savi) Ten. (Asteraceae), Flaveria bidentis (L.) Kuntze (Asteraceae), Conyza spp. (Asteraceae) and others, which were probably all accidentally introduced or had moved unaided into the ecosystem from adjoining areas. These species were mainly confined to roadsides or other man-made disturbances and were not

TABLE 1: Alien plant species, including some native plant species which may be growing outside of their natural range, recorded in the Serengeti-Mara ecosystem and immediate surrounds (excluding vegetable crops and grains).

\begin{tabular}{|c|c|c|c|c|}
\hline Species & Family & $\begin{array}{l}\text { Number of tourist } \\
\text { facilities where species } \\
\text { was cultivated }\end{array}$ & $\begin{array}{l}\text { Naturalised within } \\
\text { tourist facilities }\end{array}$ & $\begin{array}{l}\text { Invasive outside of } \\
\text { tourist facilities }\end{array}$ \\
\hline Brillantaisia lamium (Nees) Benth. & Acanthaceae & 3 & Yes & No \\
\hline Hypoestes aristata (Vahl) Roem. \& Schult. & Acanthaceae & 1 & No & No \\
\hline Hypoestes phyllostachya Baker & Acanthaceae & Clark et al. (2010) & & \\
\hline Odontonema tubaeforme (Bertol.) Kuntze & Acanthaceae & 1 & No & No \\
\hline Ruellia simplex C. Wright & Acanthaceae & 1 & No & No \\
\hline Thunbergia grandiflora (Roxb. ex Rottl.) Roxb. & Acanthaceae & 2 & No & No \\
\hline Thunbergia mysorensis (Wight) T. Anderson & Acanthaceae & 1 & No & No \\
\hline Sambucus nigra L. ssp. canadensis (L.) R. Bolli & Adoxaceae & 1 & No & No \\
\hline Agave attenuata Salm-Dyck & Asparagaceae & 3 & No & No \\
\hline Agave americana $\mathrm{L}$. & Asparagaceae & 12 & Yes & No \\
\hline Agave angustifolia Haw. var. angustifolia & Asparagaceae & 3 & Yes & Yes \\
\hline Agave sisalana Perrine & Asparagaceae & 12 & Yes & No \\
\hline Carpobrotus edulis (L.) N.E. Br. & Aizoaceae & 1 & No & No \\
\hline $\begin{array}{l}\text { Mesembryanthemum cordifolium L.f. [Syn.: Aptenia cordifolia } \\
\text { (L.f.) Schwantes] }\end{array}$ & Aizoaceae & 9 & No & No \\
\hline Amaranthus hybridus L. & Amaranthaceae & 0 & Yes & Yes \\
\hline Alternanthera pungens Kunth & Amaranthaceae & 0 & Yes & Yes \\
\hline Gomphrena celosioides Mart. & Amaranthaceae & 0 & Yes & Yes \\
\hline Iresine diffusa Humb. \& Bonpl. ex Willd. & Amaranthaceae & Clark et al. (2010) & & \\
\hline Iresine herbstii Hook. & Amaranthaceae & 2 & No & No \\
\hline Agapanthus praecox Willd. & Amaryllidaceae & 3 & No & No \\
\hline $\begin{array}{l}\text { Allium neapolitanum Cirillo [Syn.: Nothoscordum inodorum } \\
\text { (Aiton) G. Nicholson] }\end{array}$ & Amaryllidaceae & 3 & Yes & Yes \\
\hline Clivia miniata (Lindl.) Bosse & Amaryllidaceae & 1 & No & No \\
\hline Hymenocallis littoralis (Jacq.) Salisb. & Amaryllidaceae & 1 & No & No \\
\hline Tulbaghia fragrans Verd. & Amaryllidaceae & 5 & No & No \\
\hline Tulbaghia violacea Harv. & Amaryllidaceae & 1 & No & No \\
\hline Schinus terebinthifolius Raddi & Anacardiaceae & 4 & No & No \\
\hline Annona montana Macfad. & Annonaceae & Clark et al. (2010) & & \\
\hline Polyalthia longifolia (Sonn.) Thwaites & Annonaceae & Clark et al. (2010) & & \\
\hline Calotropis gigantea (L.) Dryand. & Apocynaceae & 0 & No & Yes \\
\hline $\begin{array}{l}\text { Cascabela thevetia (L.) Lippold [Syn.: Thevetia peruviana } \\
\text { (Pers.) K. Schum.] }\end{array}$ & Apocynaceae & 2 & No & Yes \\
\hline Catharanthus roseus (L.) G. Don & Apocynaceae & 11 & Yes & Yes \\
\hline Plumeria rubra $\mathrm{L}$. & Apocynaceae & 4 & No & No \\
\hline Nerium oleander $\mathrm{L}$. & Apocynaceae & 7 & No & No \\
\hline Vinca major L. & Apocynaceae & $\begin{array}{l}\text { Clark et al. (2010); } \\
\text { Henderson (2002) }\end{array}$ & & \\
\hline Aglaonema commutatum Schott & Araceae & Clark et al. (2010) & & \\
\hline Alocasia sp. & Araceae & 2 & No & No \\
\hline Anthurium andraeanum Linden & Araceae & 2 & No & No \\
\hline Anthurium sp. & Araceae & Clark et al. (2010) & & \\
\hline Colocasia esculenta (L.) Schott & Araceae & 1 & No & No \\
\hline Dieffenbachia maculata (Lodd.) Sweet & Araceae & 4 & No & No \\
\hline Epipremnum aureum (Linden \& André) G.S. Bunting & Araceae & Clark et al. (2010) & & \\
\hline Epipremnum pinnatum (L.) Engl. & Araceae & Clark et al. (2010) & & \\
\hline Monstera deliciosa Liebm. & Araceae & 8 & No & No \\
\hline
\end{tabular}

Source: The list was compiled from three sources: (1) surveys within the grounds of tourist accommodation facilities in the Masai-Mara National Reserve, (2) extensive road surveys throughout the region, and (3) species recorded in the Ngorongoro Conservation Area by Henderson (2002) and Clark et al. (2010) 
TABLE 1: (Continues...) Alien plant species, including some native plant species which may be growing outside of their natural range, recorded in the Serengeti-Mara ecosystem and immediate surrounds (excluding vegetable crops and grains).

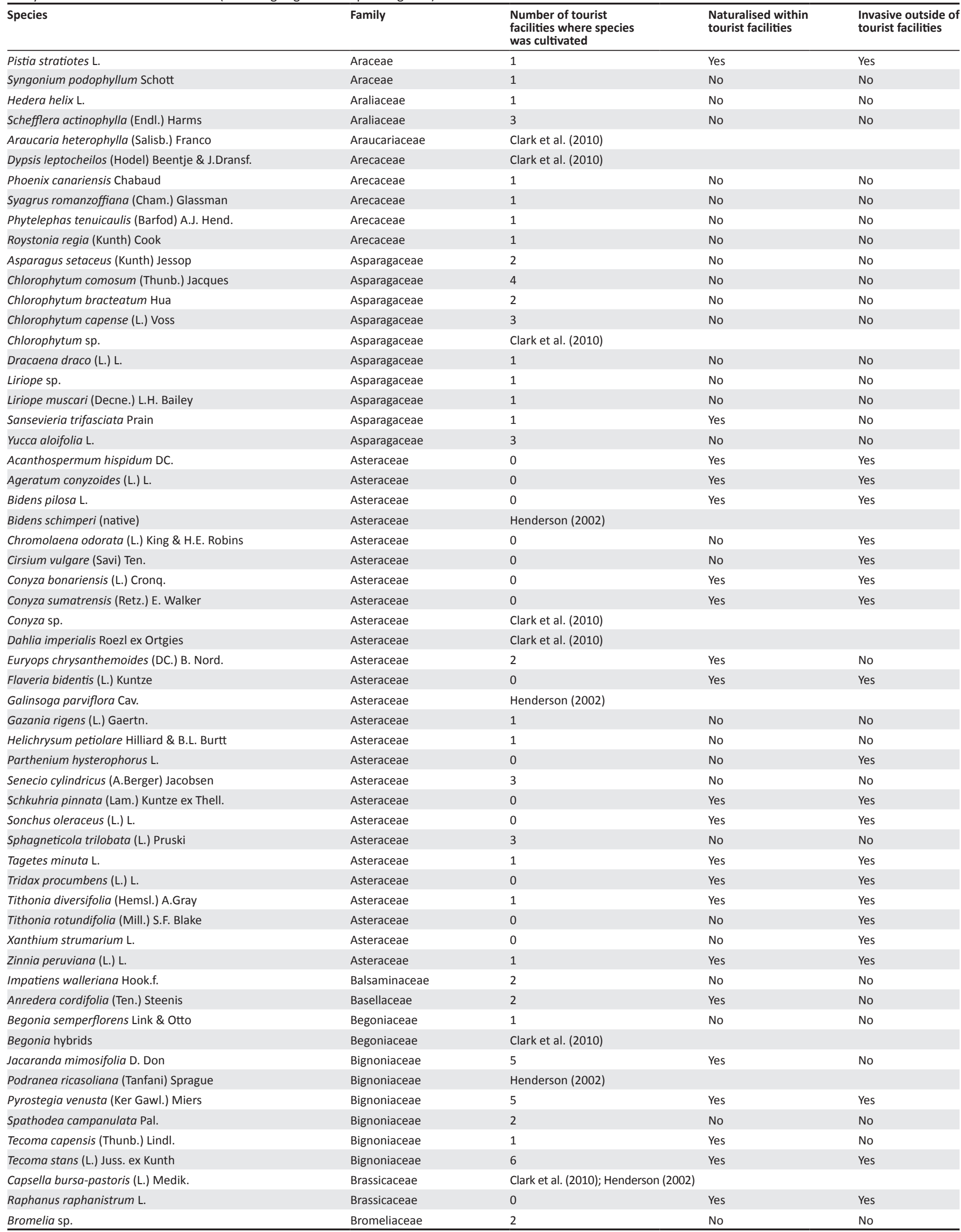

Source: The list was compiled from three sources: (1) surveys within the grounds of tourist accommodation facilities in the Masai-Mara National Reserve, (2) extensive road surveys throughout the region, and (3) species recorded in the Ngorongoro Conservation Area by Henderson (2002) and Clark et al. (2010) 
TABLE 1: (Continues...) Alien plant species, including some native plant species which may be growing outside of their natural range, recorded in the Serengeti-Mara ecosystem and immediate surrounds (excluding vegetable crops and grains).

\begin{tabular}{|c|c|c|c|c|}
\hline Species & Family & $\begin{array}{l}\text { Number of tourist } \\
\text { facilities where species } \\
\text { was cultivated }\end{array}$ & $\begin{array}{l}\text { Naturalised within } \\
\text { tourist facilities }\end{array}$ & $\begin{array}{l}\text { Invasive outside of } \\
\text { tourist facilities }\end{array}$ \\
\hline Cryptanthus bromelioides Otto \& A. Dietr. & Bromeliaceae & 1 & No & No \\
\hline Austrocylindropuntia subalata (Muehlenpf.) Backeb. & Cactaceae & 2 & No & Yes \\
\hline Cereus jamacaru DC. & Cactaceae & 5 & No & No \\
\hline Opuntia ficus-indica (L.) Mill. & Cactaceae & 4 & Yes & Yes \\
\hline Opuntia monacantha (Willd.) Haw. & Cactaceae & 7 & Yes & Yes \\
\hline Cannabis sativa $\mathrm{L}$. & Cannabaceae & Clark et al. (2010) & & \\
\hline Canna indica L. & Cannaceae & 10 & Yes & No \\
\hline Canna $\times$ generalis L.H. Bailey \& E.Z. Bailey & Cannaceae & 2 & No & No \\
\hline Cleome gynandra L. & Capparaceae & 0 & Yes & Yes \\
\hline Lonicera japonica Thunb. & Caprifoliaceae & 1 & No & No \\
\hline Carica papaya L. & Caricaceae & 1 & Yes & No \\
\hline Casuarina equisetifolia $\mathrm{L}$. & Casuarinaceae & Clark et al. (2010) & & \\
\hline Terminalia mantaly H. Perrier & Combretaceae & 4 & No & No \\
\hline Terminalia superba Engl. \& Diels & Combretaceae & Clark et al. (2010) & & \\
\hline Callisia fragrans (Lindl.) Woodson & Commelinaceae & 5 & Yes & No \\
\hline Callisia repens (Jacq.) L. & Commelinaceae & 3 & Yes & No \\
\hline Tradescantia pallida (Rose) D.R. Hunt & Commelinaceae & 2 & Yes & No \\
\hline Tradescantia zebrina Bosse & Commelinaceae & 13 & Yes & No \\
\hline Ipomoea cairica (L.) Sweet (native) & Convolvulaceae & 2 & Yes & Yes \\
\hline Ipomoea hildebrandtii Vatke (native) & Convolvulaceae & 2 & Yes & Yes \\
\hline Bryophyllum delagoense (Eckl. \& Zeyh.) Druce & Crassulaceae & 12 & Yes & Yes \\
\hline $\begin{array}{l}\text { Bryophyllum fedtschenkoi (Raym.-Hamet \& H. Perrier) } \\
\text { Lauz.-March. }\end{array}$ & Crassulaceae & 11 & No & No \\
\hline Bryophyllum proliferum Bowie ex Hook. & Crassulaceae & 8 & Yes & No \\
\hline Cotyledon orbiculata L. & Crassulaceae & 1 & No & No \\
\hline Crassula multiclava Lem. & Crassulaceae & 5 & Yes & No \\
\hline Crassula ovata (Mill.) Druce & Crassulaceae & 9 & ? No & No \\
\hline Kalanchoe blossfeldiana Poelln. & Crassulaceae & 1 & No & No \\
\hline Kalanchoe longiflora Schltr. ex J.M. Wood & Crassulaceae & 1 & No & No \\
\hline Kalanchoe sp. 1 & Crassulaceae & 1 & No & No \\
\hline Kalanchoe sp. 2 & Crassulaceae & 1 & No & No \\
\hline Cupressus lusitanica Mill. & Cupressaceae & 1 & No & No \\
\hline Cupressus sempervirens $\mathrm{L}$. & Cupressaceae & Clark et al. (2010) & & \\
\hline Widdringtonia nodiflora (L.) E. Powrie & Cupressaceae & Clark et al. (2010) & & \\
\hline Cyathea australis (R. Br.) Domin & Cyathaceae & 1 & No & No \\
\hline Acalypha amentacea Roxb. & Euphorbiaceae & 1 & No & No \\
\hline Acalypha wilkesiana Müll. Arg. & Euphorbiaceae & 3 & No & No \\
\hline Euphorbia cotinifolia L. & Euphorbiaceae & 3 & No & No \\
\hline Euphorbia pulcherrima Willd. ex Klotzsch & Euphorbiaceae & 6 & No & No \\
\hline $\begin{array}{l}\text { Euphorbia milii var. splendens (Bojer ex Hook.) Ursch \& Leandri } \\
\text { (Syn.: Euphorbia splendens Bojer ex Hook.) }\end{array}$ & Euphorbiaceae & 12 & No & No \\
\hline Hura crepitans L. & Euphorbiaceae & Clark et al. (2010) & & \\
\hline Jatropha podagrica Hook. & Euphorbiaceae & 2 & No & No \\
\hline Jatropha sp. & Euphorbiaceae & Clark et al. (2010) & & \\
\hline Pedilanthus tithymaloides (L.) Poit & Euphorbiaceae & 3 & No & No \\
\hline Ricinus communis L. (? native) & Euphorbiaceae & 4 & Yes & Yes \\
\hline Acacia mearnsii De Wild. & Fabaceae & Clark et al. (2010); Henderson (2002) & & \\
\hline Acrocarpus fraxinifolius Arn. & Fabaceae & 1 & No & No \\
\hline Albizia lebbeck (L.) Benth. & Fabaceae & 1 & No & No \\
\hline Bauhinia variegata $\mathrm{L}$. & Fabaceae & 2 & No & No \\
\hline Caesalpinia decapetala (Roth) Alston & Fabaceae & 0 & No & Yes \\
\hline Caesalpinia pulcherrima (L.) Sw. & Fabaceae & Clark et al. (2010) & & \\
\hline Calliandra calothyrsus Meisn. & Fabaceae & 2 & No & No \\
\hline Chrysanthemum sp. & Fabaceae & 4 & No & No \\
\hline Delonix regia (Hook.) Raf. & Fabaceae & 1 & No & No \\
\hline Leucaena leucocephala (Lam.) de Wit & Fabaceae & 7 & Yes & Yes \\
\hline
\end{tabular}

Source: The list was compiled from three sources: (1) surveys within the grounds of tourist accommodation facilities in the Masai-Mara National Reserve, (2) extensive road surveys throughout the region, and (3) species recorded in the Ngorongoro Conservation Area by Henderson (2002) and Clark et al. (2010) 
TABLE 1: (Continues...) Alien plant species, including some native plant species which may be growing outside of their natural range, recorded in the Serengeti-Mara ecosystem and immediate surrounds (excluding vegetable crops and grains).

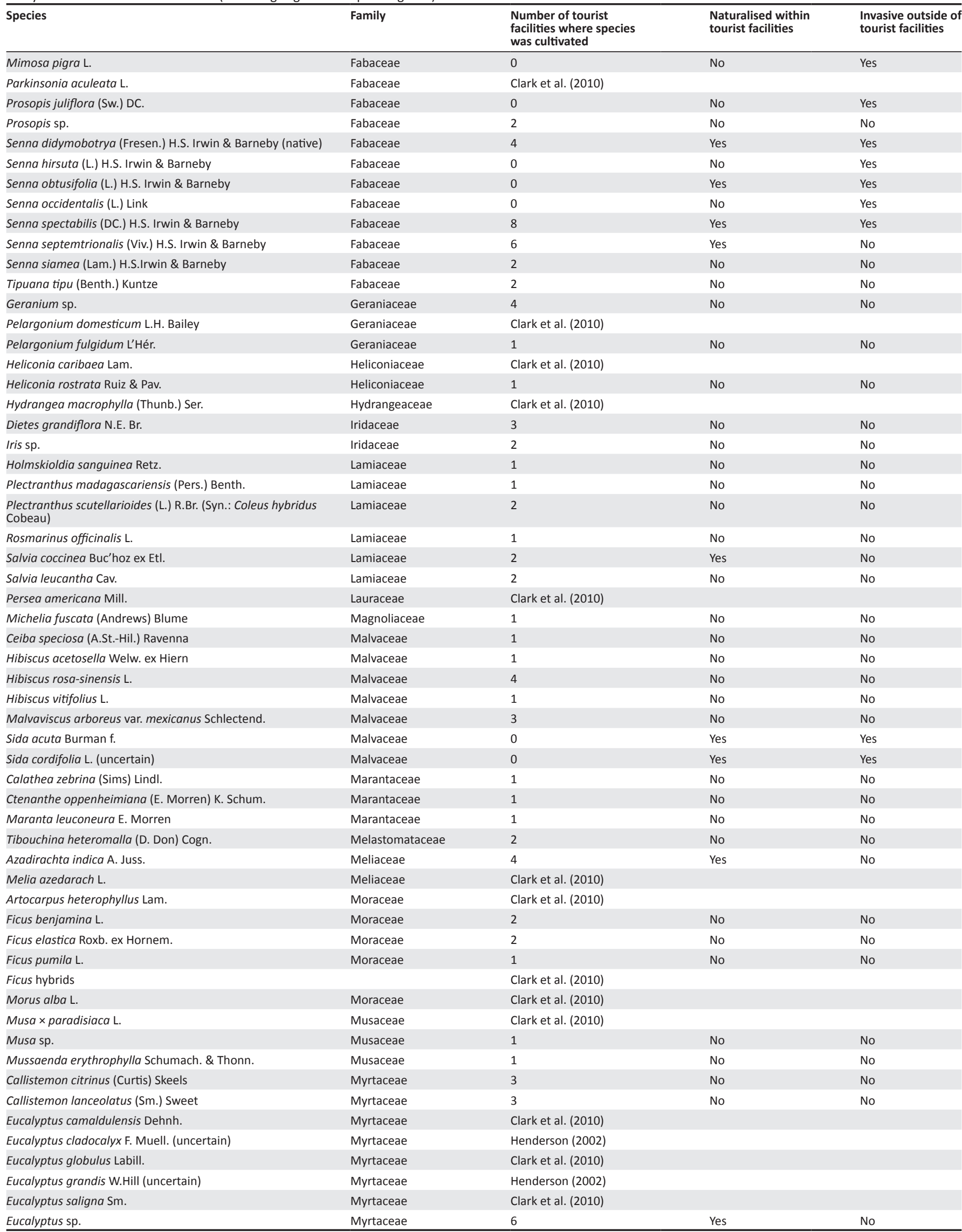

Source: The list was compiled from three sources: (1) surveys within the grounds of tourist accommodation facilities in the Masai-Mara National Reserve, (2) extensive road surveys throughout the region, and (3) species recorded in the Ngorongoro Conservation Area by Henderson (2002) and Clark et al. (2010) 
TABLE 1: (Continues...) Alien plant species, including some native plant species which may be growing outside of their natural range, recorded in the Serengeti-Mara ecosystem and immediate surrounds (excluding vegetable crops and grains).

\begin{tabular}{|c|c|c|c|c|}
\hline Species & Family & $\begin{array}{l}\text { Number of tourist } \\
\text { facilities where species } \\
\text { was cultivated }\end{array}$ & $\begin{array}{l}\text { Naturalised within } \\
\text { tourist facilities }\end{array}$ & $\begin{array}{l}\text { Invasive outside of } \\
\text { tourist facilities }\end{array}$ \\
\hline Melaleuca armillaris (Sol. ex Gaertn.) Sm. & Myrtaceae & 2 & No & No \\
\hline Psidium guajava $\mathrm{L}$. & Myrtaceae & 3 & Yes & Yes \\
\hline Syzygium cumini (L.) Skeels & Myrtaceae & 1 & No & No \\
\hline Nephrolepis exaltata (L.) Schott (uncertain) & Nephrolepidaceae & 8 & Yes & No \\
\hline Bougainvillea spectabilis Willd. (uncertain) & Nyctaginaceae & Clark et al. (2010) & & \\
\hline Mirabilis jalapa L. & Nyctaginaceae & 2 & Yes & No \\
\hline Jasminum polyanthum Franch & Oleaceae & 1 & No & No \\
\hline Fuchsia sp. & Onagraceae & Clark et al. (2010) & & \\
\hline Ludwigia adscendens ssp. diffusa (Forssk.) P.H. Raven & Onagraceae & Clark et al. (2010) & & \\
\hline Oxalis latifolia Kunth & Oxalidaceae & 0 & Yes & Yes \\
\hline Argemone ochroleuca Sweet & Papaveraceae & 0 & No & Yes \\
\hline Argemone mexicana $\mathrm{L}$. & Papaveraceae & 0 & No & Yes \\
\hline Passiflora subpeltata Ortega & Passifloraceae & 4 & Yes & Yes \\
\hline Peperomia obtusifolia (L.) A. Dietr. (uncertain) & Piperaceae & 1 & No & No \\
\hline Russelia equisetiformis Schltdl. \& Cham. & Plantaginaceae & 1 & No & No \\
\hline Plumbago auriculata Lam. & Plumbaginaceae & 3 & No & No \\
\hline Pennisetum setaceum var. rubrum (Forssk.) Chiov. & Poaceae & 3 & No & No \\
\hline $\begin{array}{l}\text { Yushania alpina (K.Schum.) W.C. Lin (Syn.: Arundinaria alpina K. } \\
\text { Schum.) (uncertain) }\end{array}$ & Poaceae & 1 & No & No \\
\hline Arundinaria disticha Pfitzer (uncertain) & Poaceae & 1 & No & No \\
\hline Bambusa nutans Wall. ex Munro & Poaceae & 4 & No & No \\
\hline Pennisetum setaceum (Forssk.) Chiov. (native) & Poaceae & 2 & No & No \\
\hline Pontederia cordata $\mathrm{L}$. & Pontederiaceae & 2 & Yes & No \\
\hline Grevillea robusta A.Cunn. ex R. Br. & Proteaceae & 10 & No & No \\
\hline Cotoneaster pannosus Franch. & Rosaceae & 1 & No & No \\
\hline Eriobotrya japonica (Thunb.) Lindl. & Rosaceae & 1 & No & No \\
\hline Malus domestica Borkh. & Rosaceae & Clark et al. (2010) & & \\
\hline Rosa sp. & Rosaceae & 2 & No & No \\
\hline Coffea arabica $\mathrm{L}$. & Rubiaceae & Clark et al. (2010) & & \\
\hline Hamelia patens Jacq. & Rubiaceae & 5 & No & No \\
\hline Citrus limon (L.) Osbeck & Rutaceae & Clark et al. (2010) & & \\
\hline Citrus sinensis (L.) Osbeck & Rutaceae & Clark et al. (2010) & & \\
\hline Citrus sp. & Rutaceae & 2 & No & No \\
\hline Azolla filiculoides Lam. (possibly Azolla cristata Kaulf.) & Salvinaceae & Clark et al. (2010) & & \\
\hline Bergenia ciliata (Haw.) Sternb. & Saxifragaceae & 1 & No & No \\
\hline $\begin{array}{l}\text { Brugmansia suaveolens (Humb. \& Bonpl. ex Willd.) Bercht. \& J. } \\
\text { Presl }\end{array}$ & Solanaceae & 1 & Yes & No \\
\hline $\begin{array}{l}\text { Brunfelsia uniflora (Pohl) D. Don [Syn.: Brunfelsia hopeana } \\
\text { (Hook.) Benth.] }\end{array}$ & Solanaceae & 1 & No & No \\
\hline Capsicum annuum L. (Syn.: Capsicum frutescens L.) & Solanaceae & Clark et al. (2010) & & \\
\hline Cestrum aurantiacum Lindl. & Solanaceae & Clark et al. (2010) & & \\
\hline Cestrum elegans (Brongn. ex Neumann) Schltdl. & Solanaceae & 1 & No & No \\
\hline Cestrum nocturnum $\mathrm{L}$. & Solanaceae & 1 & No & No \\
\hline Cyphomandra betacea (Cav.) Sendtn. (unresolved name) & Solanaceae & Clark et al. (2010) & & \\
\hline Datura stramonium L. & Solanaceae & 0 & No & Yes \\
\hline $\begin{array}{l}\text { Lycianthes rantonnei (Carrière) Bitter (Syn.: Solanum rantonnetii } \\
\text { Carrière) }\end{array}$ & Solanaceae & 1 & No & No \\
\hline Nicandra physalodes (L.) Gaertn. & Solanaceae & 0 & Yes & Yes \\
\hline Nicotiana glauca Graham & Solanaceae & Clark et al. (2010) & & \\
\hline Nicotiana tabacum L. & Solanaceae & Clark et al. (2010) & & \\
\hline Solanum campylacanthum A. Rich (native) & Solanaceae & 0 & Yes & Yes \\
\hline Solanum mauritianum Scop. & Solanaceae & 7 & Yes & Yes \\
\hline Solanum seaforthianum Andrews & Solanaceae & 2 & Yes & No \\
\hline Withania somnifera (L.) Dunal & Solanaceae & Clark et al. (2010) & & \\
\hline Strelitzia reginae Banks & Strelitziaceae & 5 & No & No \\
\hline Talinum paniculatum (Jacq.) Gaertn. & Talinaceae & 1 & Yes & No \\
\hline
\end{tabular}

Source: The list was compiled from three sources: (1) surveys within the grounds of tourist accommodation facilities in the Masai-Mara National Reserve, (2) extensive road surveys throughout the region, and (3) species recorded in the Ngorongoro Conservation Area by Henderson (2002) and Clark et al. (2010) 
TABLE 1: (Continues...) Alien plant species, including some native plant species which may be growing outside of their natural range, recorded in the Serengeti-Mara ecosystem and immediate surrounds (excluding vegetable crops and grains).

\begin{tabular}{|c|c|c|c|c|}
\hline Species & Family & $\begin{array}{l}\text { Number of tourist } \\
\text { facilities where species } \\
\text { was cultivated }\end{array}$ & $\begin{array}{l}\text { Naturalised within } \\
\text { tourist facilities }\end{array}$ & $\begin{array}{l}\text { Invasive outside of } \\
\text { tourist facilities }\end{array}$ \\
\hline Tropaeolum majus L. & Tropaeolaceae & Henderson (2002) & & \\
\hline Aloysia citriodora Palau [Syn.: Lippia citriodora (Palau) Kunth] & Verbenaceae & 1 & No & No \\
\hline Duranta erecta L. & Verbenaceae & 11 & No & No \\
\hline Lantana camara L. & Verbenaceae & 12 & Yes & Yes \\
\hline Lantana montevidensis (Spreng.) Briq. & Verbenaceae & 1 & No & No \\
\hline Petrea volubilis L. & Verbenaceae & 2 & No & No \\
\hline Verbena bonariensis $\mathrm{L}$. & Verbenaceae & 1 & Yes & Yes \\
\hline Verbena hybrida Groenl. \& Rumpler & Verbenaceae & 1 & No & No \\
\hline Verbena officinalis $\mathrm{L}$. & Verbenaceae & 2 & No & Yes \\
\hline Aloe sp. & Xanthorrhoeaceae & 5 & No & No \\
\hline Bulbine asphodeloides (L.) Spreng. & Xanthorrhoeaceae & 1 & No & No \\
\hline Bulbine latifolia (L.f.) Spreng. (Syn.: Bulbine natalensis Baker) & Xanthorrhoeaceae & 2 & No & No \\
\hline Hemerocallis fulva (L.) L. & Xanthorrhoeaceae & 1 & No & No \\
\hline Phormium tenax J.R. Forst. \& G. Forst. & Xanthorrhoeaceae & 1 & No & No \\
\hline Alpinia purpurata (Vieill.) K.Schum. & Zingiberaceae & 1 & No & No \\
\hline Alpinia zerumbet (Pers.) B.L. Burtt \& R.M. Sm. & Zingiberaceae & 1 & No & No \\
\hline Curcuma zedoaria (Christm.) Roscoe & Zingiberaceae & Clark et al. (2010) & & \\
\hline Zingiber neglectum Valeton & Zingiberaceae & Clark et al. (2010) & & \\
\hline Tribulus terrestris $\mathrm{L}$. & Zygophyllaceae & 0 & Yes & Yes \\
\hline Unknown sp. A - H (8 spp.) & Unknown & 1 & No & No \\
\hline
\end{tabular}

Source: The list was compiled from three sources: (1) surveys within the grounds of tourist accommodation facilities in the Masai-Mara National Reserve, (2) extensive road surveys throughout the region, and (3) species recorded in the Ngorongoro Conservation Area by Henderson (2002) and Clark et al. (2010)

regarded as being transformers as described by Richardson et al. (2000), in that they probably have negligible impacts on biodiversity or ecosystems over a large area. However, other species such as P. hysterophorus, which were probably also accidentally introduced or moved into the ecosystem unaided, are already widespread and abundant and pose a significant threat to biodiversity. A large number of alien species have also been intentionally introduced. Of the 245 alien plant species seen and recorded in the ecosystem (including Ipomoea hildebrandtii Vatke [Convolvulaceae], Ipomoea cairica [L.] Sweet, S. didymobotrya and R. communis which are native to the region but may have been intentionally introduced into the ecosystem as ornamentals, and excluding the additional species recorded by Clark et al. [2010] and Henderson [2002]), 212 species were considered to have been intentionally introduced, mainly as ornamentals, in tourism accommodation facilities (Table 1). Of those 212 alien ornamental plant species seen in tourist facilities, 51 were considered to be naturalised in that they had spread and established self-perpetuating populations within the tourist compounds, often in natural vegetation. Species such as Callisia repens (Lindl.) Woodson (Commelinaceae) had established large populations in woodland understoreys of some lodges together with Tradescantia zebrina (Rose) D.R. Hunt (Commelinaceae), while climbers or creepers such as Pyrostegia venusta (Ker Gawl.) Miers (Bignoniaceae), Tecoma capensis (Thunb.) Lindl. (Bignoniaceae), Solanum seaforthianum Andrews (Solanaceae) and others had invaded woodlands, scrambling or climbing over native trees and contributing to canopy collapse. Of these naturalised ornamentals, 23 species appeared to have spread beyond the facility fences or other human habitation, where they were also being cultivated, and established populations in the adjacent natural vegetation (Table 1). These included species such as Catharanthus roseus (L.) G. Don (Apocynaceae), Zinnia peruviana (L.) L. (Asteraceae), T. diversifolia, Solanum mauritianum Scop. (Solanaceae), Senna spectabilis (DC.) H.S. Irwin \& Barneby (Fabaceae), L. camara and Tecoma stans (L.) Juss. ex Kunth. (Bignoniaceae). Although the cactus species Opuntia monacantha (Willd.) Haw. (Cactaceae) and Austrocylindropuntia subalata (Muehlenpf.) Backeb. were present in lodge gardens in the Masai-Mara National Reserve, and adjoining conservancies, they were not found to be invasive, unlike the situation within the Serengeti National Park and surrounding conservation areas where the former had escaped cultivation and established populations in the wild. Opuntia stricta and C. decapetala were not seen in any tourism facilities but were widely grown, especially as living fences, in villages within and immediately adjacent to the Serengeti-Mara ecosystem from where they have established populations in the natural vegetation. Another species that is probably not cultivated but nevertheless abundant on the edge of the ecosystem is $C$. odorata.

Our second roadside survey of the extent of P. hysterophorus in the Masai-Mara National Reserve revealed a significant densification of $P$. hysterophorus infestations within the National Reserve Central Plains and the establishment of numerous new infestations to the east (Figure 3). However, intensive management in the form of ongoing control of $P$. hysterophorus over several years, using manual (handpulling) and chemical (Tordon 101 containing the active ingredients Picloram and 2,4-D) control interventions in the adjacent 'Mara Triangle' resulted in a reduction in the 


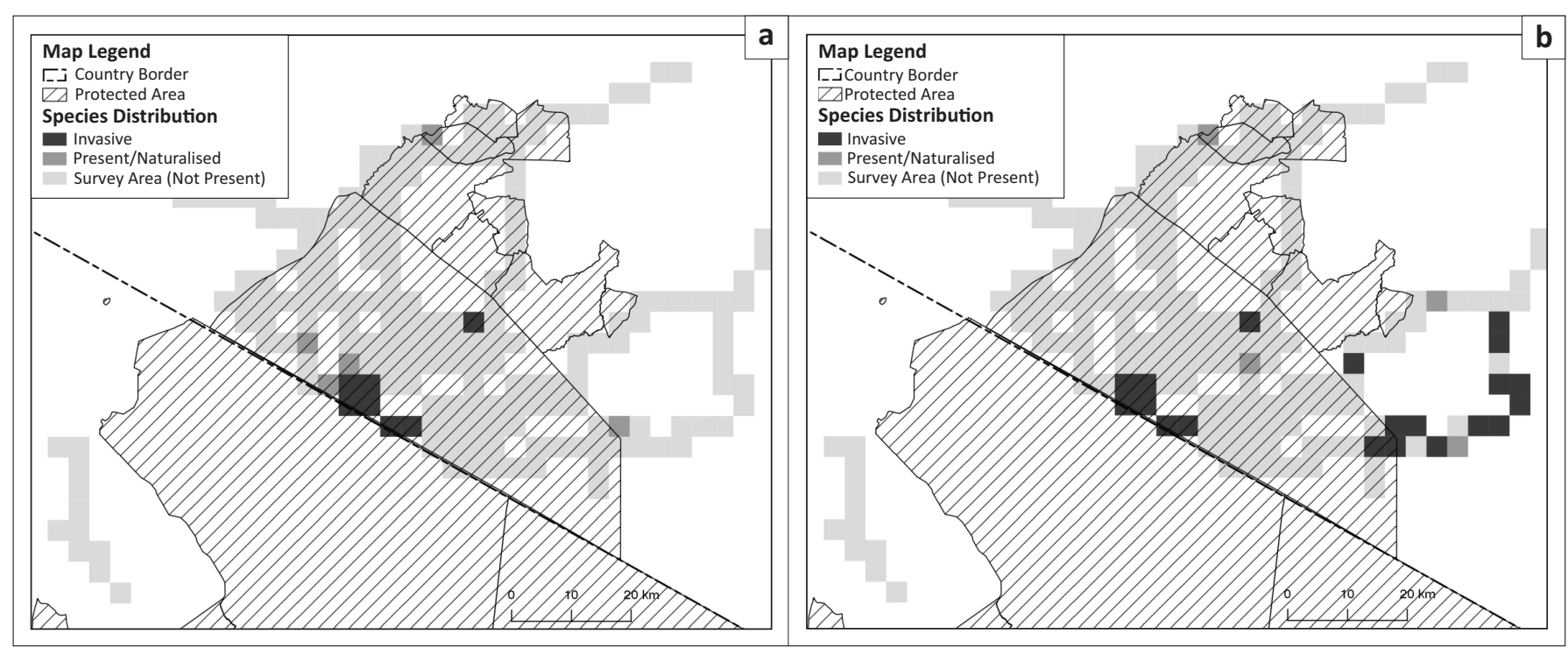

FIGURE 3: Successive surveys in (a) 2011 and (b) 2016 of Parthenium hysterophorus in the Masai-Mara National Reserve and surrounding areas in Kenya, showing the establishment of new populations to the east of the Reserve by 2016.

distribution and abundance of this noxious weed. This provides an illustration of what can potentially be achieved with focussed management programmes, especially when infestations are still small and localised. These efforts need to be expanded because much of this conservation area is under threat from further P. hysterophorus invasions.

Overall, our extensive roadside surveys revealed that the Serengeti-Mara ecosystem is currently relatively free of transforming invasive alien plants, with the exception of relatively small localised populations of L. camara, T. diversifolia, O. stricta, Opuntia ficus-indica, and O. monacantha, with more extensive and widespread infestations of P. hysterophorus in the Masai-Mara National Reserve and adjoining conservancies (Figure 4). Unless they are managed, these infestations are likely to expand, as the results of our second survey on P. hysterophorus in 2016 clearly demonstrated. This is very likely considering that climate suitability maps, developed by Kriticos et al. (2015) and McConnachie et al. (2011), indicate that most of the Serengeti-Mara ecosystem is climatically suitable for the establishment of P. hysterophorus, especially the northwestern section (Figure 5). Other invasive plant species such as C. odorata and Prosopis juliflora, which are currently abundant outside of the ecosystem, within predominantly communal lands to the west (Figure 4), are also likely to spread into the ecosystem in the foreseeable future, if steps are not taken to prevent this.

\section{Evidence of impact of selected important species}

Our review of available literature on the impacts of six selected taxa revealed that each poses substantial threats to the Serengeti-Mara ecosystem, should they be allowed to spread and densify within the ecosystem or invade it from adjacent areas. Evidence for the main impacts are summarised below.
Opuntia stricta is a succulent shrub that was introduced from Central America, and it is regarded as a transformer species in savannas and arid grasslands (Henderson 2001). The species is highly invasive and forms dense stands, impeding movement and access across the landscape. In Madagascar, $O$. stricta has invaded land used for crop and pasture production, and has encroached on villages and roads, impeding human mobility (Larsson 2004). Here, the cactus has had a negative impact on native grasses and herbs, and affects trees by inhibiting their growth and regeneration (Larsson 2004). The small spines (known as glochids) on the fruit, when consumed by livestock, lodge in their gums, on their tongues or in their gastrointestinal tracts, causing bacterial infections, while the hard seeds may cause rumen impaction, which can be fatal and which often leads to excessive, enforced culling of affected animals (Ueckert et al. 1990). Similar impacts have been recorded in Laikipia County, Kenya, where pastoralists have lost significant numbers of livestock (Shackleton et al. in press). People who consume the fruits develop diarrhoea and may suffer from serious infections caused by the spines (Larsson 2004). In Kenya, O. stricta infestations have resulted in the abandonment of land (A.B.R. Witt pers. observ.).

Lantana camara is an invasive shrub or scrambling plant introduced from Central and South America. The species invades forest edges, savannas and degraded rangelands, where it forms dense, impenetrable thickets (Henderson 2001). The species reduces biodiversity and threatens a host of rare and endangered species. In Australia, Turner and Downey (2010) identified 275 native plant species and 24 native animal species that were threatened by L. camara. In crop production systems in Southeast Asia, lantana has both reduced yields and increased management costs incurred by growers of durian, pineapples, bananas and rubber (Waterhouse 1993). Lantana camara is also toxic to livestock, causing pastoral losses that were estimated at Aus\$ 7.7 million in Queensland, Australia, in 1985, and which included 

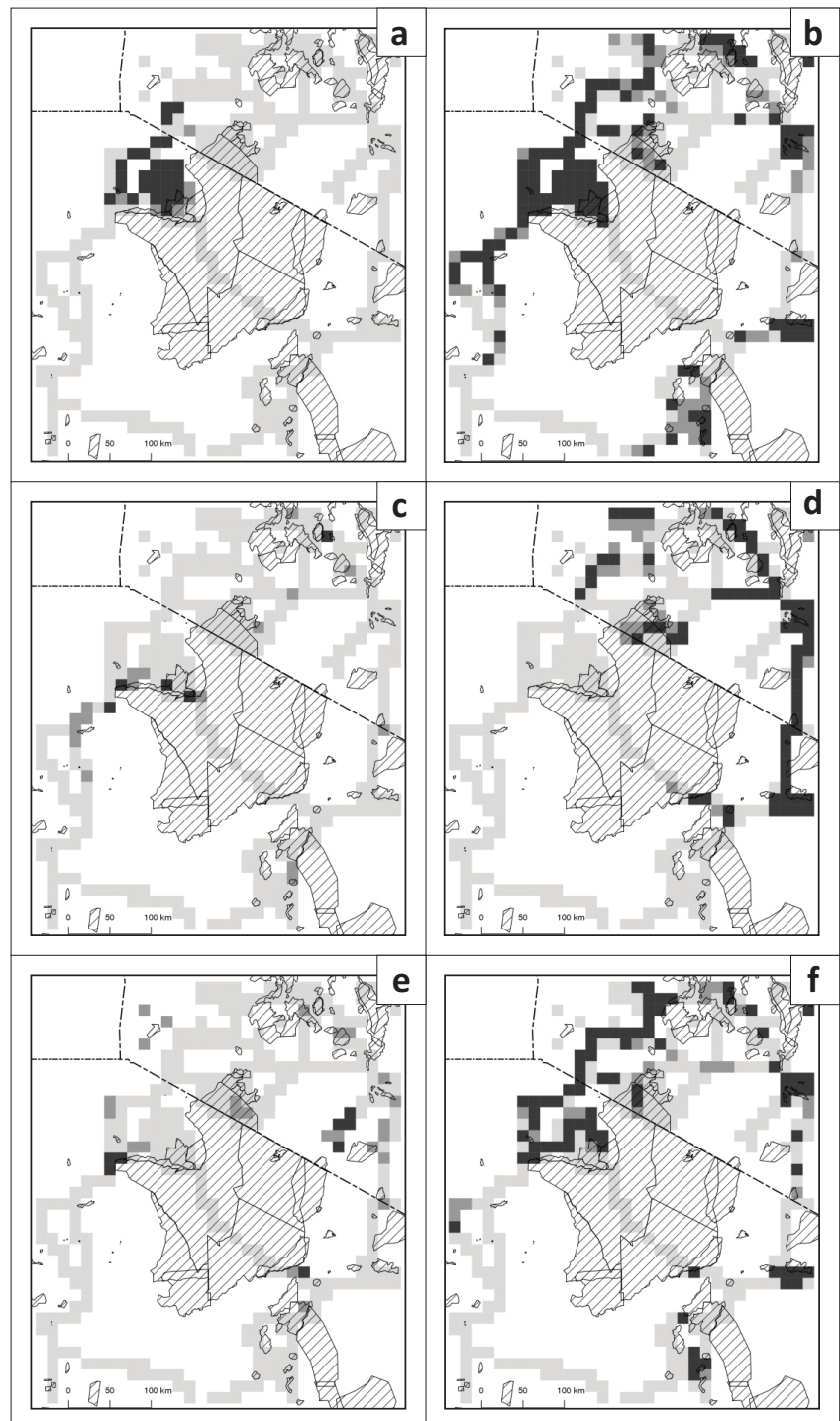

Grid cells are approximately $14 \times 14 \mathrm{~km}$. Surveyed cells where the species was not found are shaded light grey, while dark grey indicates presence and black indicates abundant and/or spreading invasions.

FIGURE 4: Distribution of six invasive alien plant species, (a) Chromolaena odorata, (b) Lantana camara, (c) Opuntia stricta, (d) Parthenium hysterophorus, (e) Prosopis species and (f) Tithonia diversifolia, in and around the SerengetiMara ecosystem, East Africa.

1500 animal deaths, reduced productivity, loss of pasture and higher control costs (Van Oosterhout 2004). In South Africa, lantana poisoning accounts for about $25 \%$ of all reported cases of livestock poisoning by plants (Wells \& Stirton 1988). There have even been recorded fatalities in people, especially children, after consuming the green fruit (CABI 2016; Sharma 2007). Lantana camara can also alter fire regimes, allowing fires to penetrate into forests and woodlands that are normally resistant to fire (Berry, Wevill \& Curran 2011; Day et al. 2003).

Parthenium hysterophorus is an annual herb native to tropical America, which has become a widespread invader of rangelands and cropping fields in at least 34 countries in Africa, Asia, Australia and the Middle East (Adkins \& Shabbir 2014). The species is allelopathic, which enables it to suppress natural vegetation in a wide range of habitats (Aggarwal \& Kohli 1992; Evans 1997; McFadyen 1992;

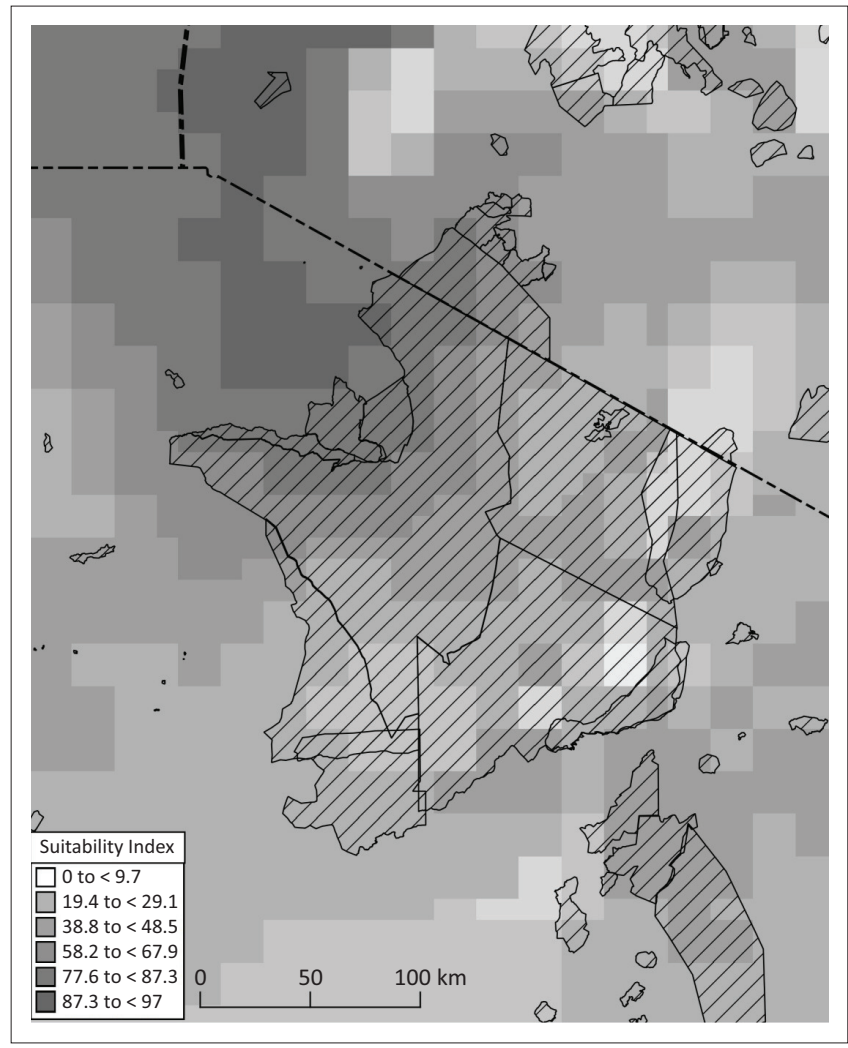

Grey shading depicts the Eco-climatic Indices (suitability of each location); the darker the shading, the more suitable the climate in that area is for Parthenium hysterophorus to establish and proliferate.

FIGURE 5: CLIMEX generated map of the relative climatic suitability of the Serengeti-Mara ecosystem and surrounding areas for Parthenium hysterophorus based on a model developed by McConnachie et al. 2011.

Van der Laan 2006), including native grasses in the Kruger National Park (Van der Laan 2006). The weed was estimated to reduce stocking rates in Queensland, Australia, by 25\% for light to medium infestations, and by as much as $80 \%$ for heavy infestations (McFadyen 1992) and by as much as $90 \%$ in India (Jayachandra 1971). Parthenium hysterophorus also causes severe allergenic reactions (dermatitis, hay fever and asthma) in a large proportion of people who come into contact with it, as well as in livestock and wildlife (Patel 2011; Towers \& Mitchell 1983). The weed is now considered, by $90 \%$ of the farmers in the lowlands of Ethiopia, to be the most serious weed of croplands and grazing areas (Tamado \& Milberg 2004).

Shrubs/trees in the genus Prosopis were introduced into East Africa in the 1980s, with some species and hybrids having already invaded over 1 million ha in Kenya, where they have the potential to invade nearly half of Kenya's surface area (Maundu et al. 2009; Witt 2010). The species, including $P$. juliflora, were originally introduced to Kenya, and have recently invaded Tanzania. Invasive Prosopis spp. are associated with many negative impacts, thereby reducing grazing capacity (Ndhlovu, Milton-Dean \& Esler 2011), eliminating many species from invaded ecosystems (Dean et al. 2002; Schachtschneider \& February 2013; Shackleton et al. 2015; Steenkamp \& Chown 1996) and reducing water resources (Dzikiti et al. 2013). Thus, despite some benefits in the form of fuelwood and edible pods (livestock fodder), 
their overall net economic contribution is negative, and set to worsen further as the species continues to spread (Wise, Van Wilgen \& Le Maitre 2012). In Ethiopia, P. juliflora has reduced understorey cover for perennial grasses from $68 \%$ to $2 \%$, and has reduced the number of grass species from seven to two (Kebede \& Coppock 2015); in South Africa, a relatively light Prosopis spp. invasion (15\% cover) led to a $34 \%$ reduction in the grazing capacity (Ndhlovu et al. 2011). By transforming habitats and eliminating pasture species, $P$. juliflora is threatening the survival of Grévy's zebra (Equus grevyi) in invaded areas (Kebede \& Coppock 2015). Dense stands reduce access and impede the movement of people and animals, while the thorns frequently cause injury. Local communities in Kenya, Sudan, Eritrea, Malawi, South Africa and Pakistan have all reported negative consequences of these invasions (Brown, Boudjelas \& De Poorter 2004; Pasiecznik et al. 2001). In semi-arid parts of Africa, Prosopis trees have depleted the natural resources on which many thousands of people depend, spawning conflict between communities over the diminishing resources.

Chromolaena odorata is a scrambling shrub introduced from Central America. It is an aggressive invader of savanna ecosystems, where it has the potential to transform the vegetation (Henderson 2001). One mature plant can produce roughly 1 million seeds per year, which enables rapid spread and the establishment of large populations over a relatively short period (Witkowski \& Wilson 2001). Its ability to form dense, impenetrable thickets leads to the displacement of native plant species (Te Beest, Esler \& Richardson 2015a), while the dry stems and leaves, which are rich in oils, also increase fire intensities (McFadyen 2004), contributing to additional biodiversity loss. In South Africa, infestations are impacting negatively on the breeding biology of the Nile crocodile (Leslie \& Spotila 2001), while in Cameroon it is displacing native species in the family Zingiberaceae, a major food source for the endangered western lowland gorilla (Van der Hoeven \& Prins 2007). In Southeast Asia, it is a serious weed affecting oil palm, rubber, coffee, cashew, fruit and forestry (Waterhouse 1993). Some agricultural areas in Southeast Asia 'have been abandoned because Siam weed [i.e. C. odorata] has taken over pasture and crops' (CRC for Weed Management 2003:1). It also causes serious health problems in livestock and people (Aterrado \& Talatala-Sanico 1988; Sajise, Palis \& Lales 1972; Soerohaldoko 1971), while significantly reducing the livestock-carrying capacities of pastures.

Tithonia diversifolia is an annual or perennial shrub introduced from Central America, which invades savannas and grasslands (Henderson 2001). The species forms dense stands which can displace native plants and the animals associated with them. Its production of numerous small, light seeds, coupled with its ability to spread vegetatively, allows it to invade and to establish readily and rapidly in new locations (Muoghalu \& Chuba 2005). In Nigeria, it was shown to reduce species diversity in invaded plots by $25 \%$ (Oludare \& Muoghalu 2014), displacing native vegetation in wetlands
(Borokini 2011), and contributing to the local extinction of valued native species, including some important medicinal plants (Oludare \& Muoghalu 2014). It is even reported to be out-competing the formidable invasive shrub $C$. odorata (Olubode, Awodoyin \& Ogunyemi 2011). As such it is now considered to be one of the most damaging of all invasive plant species in Nigeria (Borokini 2011). Tithonia diversifolia also competes with agricultural crops (Illori et al. 2010) and invasions have reportedly led to the abandonment of some farms in the Copperbelt region of Zambia (A.B.R. Witt pers. observ., 2010).

\section{Discussion}

\section{Potential impacts on the Serengeti-Mara ecosystem}

Many exotic species, that have the potential to become invasive, do not always spread rapidly when first introduced to a new environment, but the rate of spread often increases once the species has naturalised and becomes invasive. Many of the species we recorded have not been found in the Serengeti-Mara area until relatively recently, so we can reasonably expect the rate of spread into currently uninvaded areas to increase in the near future. Although it is sometimes assumed that relatively unmodified ecosystems (such as the protected areas of the Masai-Mara and Serengeti) will be resistant to invasions, there is also evidence to the contrary. For example, the establishment of $C$. odorata can be facilitated in savannas and grasslands by small-scale disturbances that create micro-sites for establishment, ultimately aiding their long-term persistence in grass-dominated areas (Te Beest, Mpandza \& Olff 2015b). This is borne out by the fact that C. odorata has aggressively invaded savanna vegetation in the Hluhluwe-Imfolozi Park in South Africa (Dumalisile 2009; Howison 2009). It cannot be assumed that these protected ecosystems will remain uninvaded. Parthenium hysterophorus is also invasive in many other protected areas in Africa, and we have observed that this species, which is often regarded as only being able to invade disturbed or over-grazed areas, establishes readily on termite mounds that are scattered across the Serengeti-Mara landscape, providing widespread foci from which further invasions can commence.

Although invasive alien plants pose substantial threats to the integrity of the Serengeti-Mara ecosystem, this has not yet been widely recognised. For example, in a recent comprehensive treatment of the ecology and conservation of the Serengeti (Sinclair et al. 2015), invasive alien plants are only mentioned once, where it is stated that:

although the exact extent of these invasions is not known, these species have taken over grasslands in other ecosystems and could exclude wildebeest from accessing critical areas in the future. (p. 168)

Given that the large numbers of grazing mammals are dependent on good-quality forage, and given further that invasions by the alien plant species currently establishing in 
the area can reduce carrying capacities by up to $90 \%$ (Jayachandra 1971; McFadyen 1992; Ndlovu et al. 2011; Yapi 2014), large impacts can be expected. For example, Ogutu et al. (2009) found that the abundance of six large grazing mammal species declined markedly and persistently throughout the Masai-Mara National Reserve between 1989 and 2003, and that the declines were contemporaneous with progressive habitat deterioration because of a range of factors, although invasion by alien plants was not considered. The Serengeti wildebeest population is regulated by food supply, and the main cause of mortality ( $75 \%$ of cases) was found to be under-nutrition (Mduma, Sinclair \& Hilborn 1999). Rampant invasion would almost certainly result in large losses of rangeland fodder, leading to drastic declines in populations of wildebeest and other large grazing mammals. A drastic decline in wildebeest numbers would trigger many changes, as wildebeest are currently remarkably abundant, and influence virtually every dynamic of the ecosystem (Grant et al. 2015). Thus, plant invasion could potentially have big effects not only on ecosystem integrity and productivity but also on tourism, which is a very important contributor to the economies of both Kenya and Tanzania.

\section{Appropriate management responses}

Given that alien plant invasions pose large threats to the Serengeti-Mara ecosystem, it would seem prudent to develop and implement control programmes to reduce the severity of these threats. We propose that three key interventions should be implemented as a matter of urgency. Firstly, all alien plant species, especially those that are known to be naturalised, invasive or potentially invasive, should be removed from the grounds of tourist facilities. Secondly, control programmes aimed at eliminating outlier populations should be implemented to slow spread. Finally, biological control solutions should be implemented wherever possible. We discuss each of these in the following sections.

Removal of alien plants around tourist facilities: All alien plants, whether invasive or not, should ideally be removed from the grounds of any developed parts of the protected areas. Tourist and staff facilities can be a major source of invasive species, and this would be best addressed by removing all alien plants while populations are still small. In the Kruger National Park, South Africa, Foxcroft and FreitagRonaldson (2007) found that the park staff played a major role in facilitating alien plant invasions. Staff members unwittingly introduced alien species into the gardens of tourist camps as well as into their own gardens, for ornamental and other uses. Many species subsequently escaped and became invasive. Attempts to remove these species began in the mid-1980s, but there was significant resistance from the residents towards the alien plant control team for many years (Foxcroft et al. 2008). This was overcome as an understanding of the problem grew, and strategies employed by the Kruger National Park team included an initial focus on high-risk species (leaving lower-risk species in place in the meantime), and clearing gardens whenever there was staff turnover that resulted in temporary vacating of houses. Similar problems can be expected in the SerengetiMara ecosystem. However, there is legislative and other support for invasive species interventions in and outside of protected areas in Africa, and specifically in Kenya, which would provide strong justification for the removal of alien species in the face of resistance (Table 2).

Implementation of control programmes: Control programmes should be initiated as soon as possible, with priority being given to lightly invaded areas, isolated populations or the edges of invading populations. Higgins, Richardson and Cowling (2000) demonstrated that clearing strategies that prioritised low-density sites dominated by juvenile alien plants proved to be significantly more cost-effective than strategies that targeted densely invaded areas. These authors also found that delaying the initiation of clearing operations considerably increased the eventual costs of control and the risks to native biodiversity. Such early interventions can be very effective, as shown by the results of clearing of P. hysterophorus in the 'Mara Triangle' (Figure 3).

Implementation of biological control: We strongly advocate the fullest possible use of biological control, which should be integrated with other control practices, wherever possible. Biological control is a safe, inexpensive and sustainable

TABLE 2: Some national, regional and African legislation, policies, conventions and treaties that make reference to invasive alien plants.

Legislative instruments Relevant provisions and authorities

The Suppression of Noxious Weeds Act, Cap 325 (Kenya)

Environmental Management and Coordination Act of 1999 (Kenya)

\section{Forest Act, 2005 (Kenya)}

National Strategy and Action Plan for the Management of Invasive Species in Kenyan Protected Areas

Wildlife Conservation and Management Act, 2013 (Kenya)

African Convention on the Conservation of Nature and Natural Resources (1968)

Protocol concerning Protected Areas and Wild Fauna and Flora in the East African Region (Nairobi, 1985)
A number of invasive plants including Eichhornia crassipes, Datura stramonium, Prosopis juliflora and Parthenium hysterophorus are listed under the Act which empowers an 'inspector' to instruct landowners to remove listed plants, failing which they may be prosecuted (National Council for Law Reporting 2012).

Section 51 (e) provides guidelines prohibiting and controlling the introduction of alien species into natural habitats. In fact, an Environmental Impact Assessment (EIA) needs to be undertaken before alien species of flora and fauna can be introduced into ecosystems (National Environment Management Authority 2016).

Section 54 (8) (a) states that any person introducing any exotic genetic material or invasive plants without authority from the Forestry Service commits an offence (Kenya Forest Service 2016).

Various objectives and actions including awareness creation, prevention, capacity development and control including the 'sensitization of law enforcers to enhance and enforce existing legislations that bar introduction of exotic species into protected areas as per the various acts' (Kanga et al. 2013).

Section 93 states that anyone knowingly introducing an invasive alien species into a wildlife conservation area, or failing to comply with the measures prescribed by the Cabinet Secretary, as set out under the Act, will be committing an offence (Kenya Wildlife Service 2016).

Requires all parties to prohibit the entry of zoological or biological species, whether indigenous or imported, wild or domesticated, that may cause harm to protected areas (African Union 2016).

Calls for the adoption of appropriate measures to prohibit the intentional or accidental introduction of alien or new species which may cause significant or harmful changes to the sub-region. Calls for contracting parties to take measures to regulate the introduction of non-indigenous animal or plant species into protected areas (Environmental Treaties and Resource Indicators 2016). 
option for gaining control of many invasive alien plant species. The main benefits of biological control are that the agents establish self-perpetuating populations and often establish throughout the range of the target weed, including areas that are not accessible for chemical or mechanical control; control of the weed is permanent; there are no negative impacts on the environment; the cost of biological control programmes is low relative to other approaches, and in most cases only requires a once-off investment; and benefits can be reaped by many stakeholders independent of their financial status and irrespective of whether they contributed to the initial research (Greathead 1995). Studies in South Africa have demonstrated phenomenal returns on investment in economic terms from biological control projects, where estimated benefit:cost ratios ranged from 8:1 up to 3726:1 (Van Wilgen \& De Lange 2011). Biological control is arguably an indispensable element of any integrated programme to control invasive alien plants, as most other interventions will fail in the long term if used in isolation. Despite this, concerns over the safety of the practice often prevent its implementation in many countries. Much of the resistance to the use of biological control arises from ignorance, but the track record of the practice suggests that this should not be the case. It was estimated that by the end of 2012, there were 1555 separate and intentional releases of 469 species of weed biological control agents against 175 species of non-native target weeds (when related taxa of unidentified plant species, such as some Opuntia species, are counted as single target weeds) (Winston et al. 2014). These so-called 'classical' biological control projects have been conducted in a total of 90 countries (Winston et al. 2014), with an excellent record of safety and success (Van Wilgen, Moran \& Hoffmann 2013).

There are already several agents that would be available for use against major weed species that currently threaten the Serengeti-Mara ecosystem. For example, infestations of O. stricta have been brought under control in the Kruger National Park, South Africa, by the introduction and establishment of a sap-sucking bug, Dactylopius opuntiae (Cockerell) (Dactylopiidae) (Foxcroft \& Hoffmann 2000; Hoffmann, Moran \& Zeller 1998). This classical biological control agent was recently released on O. stricta in Laikipia County, Kenya, where it has established and is reducing the density and spread of this invasive cactus. In Australia, the ability of P. hysterophorous to form tall and dense invasive stands has been considerably reduced through the release of multiple biological control agents, thus substantially increasing the effectiveness of other control interventions (Dhileepan \& McFadyen 2012). Work on developing suitable biological control for P. hysterophorus has been initiated in South Africa, building on the work in Australia (Strathie, McConnachie \& Retief 2011), with a number of agents already having been released in the field. A chrysomelid beetle, Zygogramma bicolorata Pallister (Chrysomelidae) has also been released in Ethiopia and around Arusha, Tanzania, although establishment in the field is yet to be confirmed. Biological control research in South Africa has also addressed
L. camara (Urban et al. 2011), with a number of these agents already present in East Africa. However, some newly released and established agents in South Africa could complement those agents already present in Kenya and Tanzania, such as the flowerbud-galling mite Aceria lantanae (Cook) (Eriophyidae) and the root-feeding flea beetle Longitarsus bethae (Chrysomelidae) (Urban et al. 2011). Attempts have been made to establish the gall-forming fly, Cecidochares connexa (Macquart) (Tephritidae), on C. odorata in northwestern Tanzania, but we will only be able to confirm establishment at the end of 2017. A number of other agents for the control of $C$. odorata have also been released and have subsequently been established in South Africa (Zachariades et al. 2011b). A number of seed-feeding beetles have been released in South Africa and elsewhere for the control of invasive Prosopis species (Zachariades et al. 2011a), and research is currently underway to develop agents that feed on the vegetative parts of this invasive tree. Research has also been initiated in South Africa to develop agents for the control of T. diversifolia (Simelane, Mawela \& Fourie 2011). It is imperative that the Kenyan and Tanzanian authorities work together to facilitate the introduction, mass rearing and release of additional classical biological control agents to complement any current and future invasive plant management strategies in the Serengeti-Mara ecosystem. Failure to do so would result in the possible demise of one of the natural wonders of the world, the annual wildebeest migration.

\section{Acknowledgements}

The authors are grateful to the JRS Biodiversity Foundation for providing resources for surveys throughout the East African region and for the production of distribution maps. Grumeti Fund provided additional information on the distribution of Chromolaena odorata. The authors extend their thanks to staff from Kenya Wildlife Service, the MasaiMara National Reserve, including Brian Heath, and others for logistical and other support. The authors would also like to thank the lodge owners and managers, who kindly allowed them access to lodge gardens and other tourist facilities. The authors thank the DST-NRF Centre of Excellence for Invasion Biology and the National Research Foundation (grant 87550 to B.v.W.). They would also like to thank the Australian High Commission, Kenya, for providing funding for initial surveys and other activities in the MasaiMara National Reserve.

\section{Competing interests}

The authors declare that they have no financial or personal relationships that may have inappropriately influenced them in writing this article.

\section{Authors' contributions}

A.B.R.W. was responsible for initiating the field surveys, which he conducted with the assistance of S.K. T.B. undertook spatial analyses and compiled the maps. The interpretation 
of results and writing of the article was shared between B.W.v.W. and A.B.R.W.

\section{References}

Adkins, S. \& Shabbir, A., 2014, 'Biology, ecology and management of the invasive parthenium weed (Parthenium hysterophorus L.)', Pest Management Science 70, 1023-1029. https://doi.org/10.1002/ps.3708

African Union, 2016, African convention on nature conservation and natural resources, viewed 23 May 2016, from https://www.au.int/web/sites/default/ files/treaties/7782-file-african_convention_conservation_nature_natural resources.pdf

Aggarwal, A. \& Kohli, R.K., 1992, 'Screening of crops for seed germination agains Parthenium hysterophorus L. Leachates', in P. Tauro \& S.S. Narwal (eds.), Proceedings of the 1st national symposium on allelopathy in agroecosystems, Hisar, India, February 1992, pp. 66-68.

Aterrado, E.D. \& Talatala-Sanico, R.L., 1988, 'Status of Chromolaena odorata research in the Philippines', in R. Muniappan (ed.), Proceedings of the first international workshop on biological control of Chromolaena odorata, Bangkok, Thailand, February 19-March 04, 1988, pp. 53-55.

Berry, Z.C., Wevill, K. \& Curran, T.J., 2011, 'The invasive weed Lantana camara increases fire risk in dry rainforest by altering fuel beds', Weed Research 51, 525-533. https://doi.org/10.1111/j.1365-3180.2011.00869.x

Borokini, T.I., 2011, 'Invasive alien plant species in Nigeria and their effects on biodiversity conservation', Tropical Conservation Science 4, 103-110. https://doi. org/10.1177/194008291100400110

Brown, L.S., Boudjelas, S. \& De Poorter, M., 2004, 100 of the world's worst invasive alien species: A selection from the global Invasive Species Database, The Invasive alien species: A selection from the global Invasive Species Database, The Invasive
Species Specialist Group (ISSG), Species Survival Commission (SSC) of the World Species Specialist Group (ISSG), Species Survival Comm
Conservation Union (IUCN), Auckland, New Zealand.

Bukombe, J.K., Mwita, M., Kittle, A. \& Kija, H., 2012, Invasion of alien plants in Serengeti: A call for management action, Tanzania Wildlife Research Institute, Arusha.

CABI, 2016, Lantana camara, in Invasive Species Compendium, CAB International, Wallingford, UK, viewed 20 June 2016, from http://www.cabi.org/isc

Clark, K., Lotter, W.D. \& Runyoro, V., 2010, Ngorongoro Conservation Area: Invasive Alien Plant Strategic Management Plan 2010, Ngorongoro Conservation Area Authority, Arusha, Tanzania.

CRC for Weed Management, 2003, Weed management guide: Siam weed or chromolaena (Chromolaena odorata), CRC for Australian Weed Management, Commonwealth Department of Environment and Heritage, Australia.

Day, M.D., Wiley, C.J., Playford, J. \& Zalucki, M.P., 2003, Lantana: Current management, status and future prospects, Status and Future Prospects, ACIAR Monograph 102 Canberra, Australia.

Dean, W.R.J., Anderson, M.D., Milton, S.J. \& Anderson, T.A., 2002, 'Avian assemblages in native Acacia and alien Prosopis drainage line woodland in the Kalahari, South Africa', Journal of Arid Environments 51 1-19. https://doi.org/10.1006/ jare.2001.0910

De Poorter, M., 2007, Invasive alien species and protected areas: A scoping report. Part 1. Scoping the scale and nature of invasive alien species threats to protected areas, impediments to invasive alien species management and means to address those impediments, Global Invasive Species Programme, Invasive Species Specialist Group, viewed 23 July 2016, from http://www.issg.org/gisp Specialist Group, viewed
publications_reports.htm

Dhileepan, K. \& McFadyen, R.C., 2012, 'Parthenium hysterophorus L. - Parthenium', in J. Cullen, M. Julien \& R. McFadyen (eds.), Biological control of weeds in Australia, pp. 448-462, CSIRO Publishing, Melbourne, Australia.
pp.

Dumalisile, L., 2009, 'Effects of Chromolaena odorata on mammalian biodiversity in Hluhluwe-iMfolozi Park, South Africa', MSc thesis, University of Pretoria, South Africa.

Dzikiti, S., Schachtschneider, K., Naiken, V., Gush, M., Moses, G. \& Le Maitre, D.C., 2013, 'Water relations and the effects of clearing invasive Prosopis trees on groundwater in an arid environment in the Northern Cape, South Africa', Journal of Arid Environments 90, 103-113. https://doi.org/10.1016/j.jaridenv. 2012.10.015

Environmental Treaties and Resource Indicators, 2016, Protocol concerning protected areas and wild fauna and flora in the eastern African region, viewed 03 May 2016, from http://sedac.ciesin.org/entri/texts/EastAfrPro.html

Evans, H.C., 1997, 'Parthenium hysterophorus: A review of its weed status and the possibilities for biological control', Biocontrol News and Information $18,89 \mathrm{~N}-98 \mathrm{~N}$.

Foxcroft, L.C. \& Freitag-Ronaldson, S., 2007, 'Seven decades of institutional learning: Managing alien plant invasions in the Kruger National Park, South Africa', Oryx 41 160-167. https://doi.org/10.1017/\$0030605307001871

Foxcroft, L.C. \& Hoffmann, J.H., 2000, 'Dispersal of Dactylopius opuntiae Cockerell (Homoptera: Dactylopiidae), a biological control agent of Opuntia stricto (Haworth.) Haworth. (Cactaceae) in the Kruger National Park', Koedoe 43, 1-5. https://doi.org/10.4102/koedoe.v43i2.194

Foxcroft, L.C., Pyšek, P., Richardson, D.M. \& Genovesi, P., 2013a, 'Plant invasions in protected areas: Patterns, problems and challenges', Springer, Dordrecht.

Foxcroft, L.C., Richardson, D.M. \& Wilson, J.R., 2008, 'Ornamental plants as invasive aliens: Problems and solutions in Kruger National Park, South Africa', Environmental Management 41, 32-51. https://doi.org/10.1007/s00267-0079027-9
Foxcroft, L.C., Witt, A. \& Lotter, W.D., 2013b, 'Icons in peril: Invasive alien plants in African protected areas', in L.C. Foxcroft, P. Pyšek, D.M. Richardson \& P. Genovesi (eds.), Plant invasions in protected areas: Patterns, problems and challenges, pp. 117-143, Springer, Dordrecht.

Grant, J., Hopcraft, C., Holdo, R.M., Mwangomo, E., Mduma, S.A.R., Thirgood, S.J. et al., 2015, 'Why are wildebeest the most abundant herbivore in the Serenget ecosystem?', in A.R.E. Sinclair, K.L. Metzger, S.A.R. Mduma \& J.M. Fryxell (eds.), Serengeti IV: Sustaining biodiversity in a coupled human-natural system, pp. 125-174, University of Chicago Press, Chicago, IL.

Greathead, D.J., 1995, 'Benefits and risks of classical biological control', in H.M.T. Hokkanen \& J.M. Lynch (eds.), Biological control: Benefits and risks, pp. 53-63, Cambridge University Press, Cambridge.

Henderson, L., 2001, Alien weeds and invasive plants, Plant Protection Research Institute Handbook No. 12, Agricultural Research Council, Pretoria.

Henderson, L., 2002, 'Problem plants in Ngorongoro Conservation Area, Tanzania', Unpublished report submitted to the NCA in November 2002, 15p

Henderson, L., 2007, 'Invasive, naturalised and casual alien plants in southern Africa: A summary based on the South African plant invaders atlas (SAPIA)', Bothalia 37, 215-248. https://doi.org/10.4102/abc.v37i2.322

Higgins, S.I., Richardson, D.M. \& Cowling, R.M., 2000, 'Using a dynamic landscape model for planning the management of alien plant invasions', Ecological Applications 10, 1833-1848. https://doi.org/10.1890/1051-0761(2000)010[1833:UADLMF]2.0. $\mathrm{CO} ; 2$

Hoffmann, J.H., Moran, V.C. \& Zeller, D.A., 1998, 'Long-term population studies and the development of an integrated management programme for control of Opuntia stricta in Kruger National Park, South Africa', Journal of Applied Ecology 35, 156-160. https://doi.org/10.1046/j.1365-2664.1998.00283.x

Howison, O.E., 2009, 'The historical spread and potential distribution of the invasive alien plant Chromolaena odorata in Hluhluwe-iMfolozi Park', MSc thesis, University of Kwazulu-Natal, Durban, South Africa.

Illori, O.J., Otusanya, O.O., Adelusi, A.A. \& Sanni, R.O., 2010, 'Allelopathic activities of some weeds in the Asteraceae family', International Journal of Botany 61, 161-163. https://doi.org/10.3923/ijb.2010.161.163

Jayachandra, J., 1971, 'Parthenium weed in Mysore state and its control', Current Science 40, 568-569.

Kanga, E., Kenana, L., Ngoru, B. \& Lala, F. (eds.), 2013, National strategy and action plan for the management of invasive species in Kenya's protected areas 20132018, Kenya Wildlife Service (KWS), Nairobi, Kenya.

Kebede, A.T. \& Coppock, D.L., 2015, 'Livestock-mediated dispersal of Prosopis juliflora imperils grasslands and the endangered Grevy's zebra in northeastern Ethiopia', Rangeland Ecology \& Management 68, 402-407. https://doi.org/10.1016/j. rama.2015.07.002

Kenya Forest Service, 2016, Special issue: Kenya Gazette Supplement No. 88 (Acts No. 7), The Forests Act, 2005, Government Printer, Nairobi, Kenya, viewed 23 May 2016, from http://www.kenyaforestservice.org/images/MMMB/forests $\% 20$ act $\% 20$ no.7\%20of\%202005.pdf

Kenya Wildlife Service, 2016, Special Issue: Kenya Gazette Supplement No. 181 (Acts No. 47), The Wildlife and Conservation Management Act, 2013, Government Printer, Nairobi, Kenya, viewed 03 June 2016, from http://www.kws.go.ke/ downloads

Kriticos, D.J., Brunel, S., Ota, N., Fried, G., Oude Lansink, A.G.J.M., Panetta, F.D. et al., 2015, 'Downscaling pest risk analyses: Identifying current and future potentially suitable habitats for Parthenium hysterophorus with particular reference to Europe and North Africa', PLoS One 10(9), e0132807. https://doi.org/10.1371/ journal.pone.0132807

Larsson, P., 2004, Introduced Opuntia spp. in southern Madagascar: Problems and opportunities, Minor Field Studies No 285, Swedish University of Agricultural Sciences, Uppsala.

Leslie, A.J. \& Spotila, J.R., 2001, 'Alien plant threatens Nile crocodile (Crocodylus niloticus) breeding in Lake St. Lucia, South Africa', Biological Conservation 98, 347-355. https://doi.org/10.1016/S0006-3207(00)00177-4

Maundu, P., Kibet, S., Morimoto, Y., Imbumi, M. \& Adeka, R., 2009, 'Impacts of Prosopis juliflora on Kenya's semi-arid and arid ecosystems and local livelihoods', Biodiversity 10, 33-50. https://doi.org/10.1080/14888386.2009.9 712842

McConnachie, A.J., Strathie, L.W., Mersie, W., Gebrehiwot, L., Zewdie, K., Abdurehim, A. et al., 2011, 'Current and potential geographical distribution of the invasive plant Parthenium hysterophorous (Asteraceae) in Eastern and Southern Africa', Weed Research 51, 71-84. https://doi.org/10.1111/j.1365-3180.2010.00820.x

McFadyen, R.C., 2004, 'Chromolaena in East Timor: History, extent and control', in M.D. Day \& R.E. McFadyen (eds.), Chromolaena in the Asia-Pacific region, Proceedings of the 6th International Workshop on biological control and management of chromolaena, Cairns, Australia, May 06-09, 2003, pp. 8.

McFadyen, R.E., 1992, 'Biological control against Parthenium weed in Australia', Crop Protection 11, 400-407. https://doi.org/10.1016/0261-2194(92)90021-V

Mduma, S.A., Sinclair, A.R.E. \& Hilborn, R., 1999, 'Food regulates the Serenget wildebeest: A 40-year record', Journal of Animal Ecology 68, 1101-1122. https:// doi.org/10.1046/j.1365-2656.1999.00352.x

Muoghalu, J.I. \& Chuba, D.K., 2005, 'Seed germination and reproductive strategies of Tithonia diversifolia (Hemsl.) Gray and Tithonia rotundifolia (PM) Blake', Applied Ecology and Environmental Research 3, 39-46. https://doi.org/10.15666/ aeer/0301_039046

National Council for Law Reporting, 2012, Laws of Kenya, suppression of Noxious Weeds Act, Chapter 325, viewed 23 May 2016, from http://kenyalaw.org/kl/ fileadmin/pdfdownloads/Acts/SuppressionofNoxiousWeedsAct_Cap325.pdf 
National Environment Management Authority, 2016, Environmental Management and Coordination Act of 1999, viewed 23 May 2016, from http://www.nema.go. ke/images/Docs/Legislation \%20and \%20Policies/Environmental\%20Act\%20 (EMCA1999)\%20.pdf

Ndhlovu, T., Milton-Dean, S.J. \& Esler, K.J., 2011, 'Impact of Prosopis (mesquite) invasion and clearing on the grazing capacity of semiarid Nama Karoo rangeland, South Africa', African Journal of Range \& Forage Science 28, 129-137. https://doi. South Africa', African Journal of Rang
org/10.2989/10220119.2011.642095

Ogutu, J.O., Piepho, H.P., Dublin, H.T., Bhola, N. \& Reid, R.S., 2009, 'Dynamics of MaraSerengeti ungulates in relation to land use changes', Journal of Zoology 278, 1-14. https://doi.org/10.1111/j.1469-7998.2008.00536.x

Olubode, O.S., Awodoyin, R.O. \& Ogunyemi, S., 2011, 'Floral diversity in the wetlands of Apete River, Eleyele Lake and Oba Dam in Ibadan, Nigeria: Its implication for biodiversity erosion', West African Journal of Applied Ecology 18, 109-119. https://doi.org/10.4314/wajae.v18i1.70319

Oludare, A. \& Muoghalu, J.I., 2014, 'Impact of Tithonia diversifolia (Hemsly) A. Gray on the soil, species diversity and composition of vegetation in lle-Ife (Southwestern Nigeria), Nigeria', International Journal of Biodiversity and Conservation 6, 555562. https://doi.org/10.5897/JJBC2013.0634

Pasiecznik, N.M., Felker, P., Harris, P.J.C., Harsh, L.N., Cruz, G., Tewari, J.C. et al., 2001 'The Prosopis juliflora-Prosopis pallida complex: A monograph', HDRA, Coventry.

Patel, S., 2011, 'Harmful and beneficial aspects of Parthenium hysterophorus: An update', Biotech 1, 1-9. https://doi.org/10.1007/s13205-011-0007-7

Pyšek, P., Richardson, D.M., Rejmánek, M., Webster, G.L, Williamson, M. \& Kirschner J., 2004, 'Alien plants in checklists and floras: Towards better communication between taxonomists and ecologists', Taxon 53, 131-143. https://doi.org/10. 2307/4135498

Rejmánek, M., Huntley, B.J., Le Roux, J.J. \& Richardson, D.M., 2017, 'A rapid survey of the invasive plant species in western Angola', African Journal of Ecology 55, 56-69. https://doi.org/10.1111/aje.12315

Richardson, D.M., Pyšek, P., Rejmanek, M., Barbour, M.G, Panetta, F.D. \& West, C.J., 2000, 'Naturalization and invasion of alien plants: Concepts and definitions', Diversity \& Distributions 6, 93-107. https://doi.org/10.1046/j.1472-4642. Diversity \&

Sajise, P.E., Palis, R.K. \& Lales, J.S., 1972, 'Chromolaena odorata imperils grassland', Pasture Newsletter 1, 1-2.

Schachtschneider, K. \& February, E.C., 2013, 'Impact of Prosopis invasion on a keystone tree species in the Kalahari Desert, Plant Ecology 214, 597-605. https://doi. org/10.1007/s11258-013-0192-z

Shackleton, R.T., Le Maitre, D.C., Van Wilgen, B.W. \& Richardson, D.M., 2015, 'The impact of invasive alien Prosopis species (mesquite) on native plants in different environments in South Africa', South African Journal of Botany 97, 25-31. https:// doi.org/10.1016/j.sajb.2014.12.008

Shackleton, R.T., Witt, A.B.R., Nunda, W. \& Richardson, D.M., 2017, 'Chromolaena odorata (Siam weed) in eastern Africa: Distribution and socioecological impacts', Biological Invasions 19, 1285-1298. https://doi.org/10.1007/s10530-016-1338-4

Shackleton, R.T., Witt, A.B.R., Merinyi, F. \& Van Wilgen, B.W., in press, 'Distribution and socio-ecological impacts of the invasive alien cactus Opuntia stricta in eastern Africa', Biological Invasions.

Sharma, O.P., 2007, 'A review of the hepatotoxic plant Lantana camara', Critical Reviews in Toxicology 37, 313-352. https://doi.org/10.1080/10408440601177863

Simelane, D.O., Mawela, K.V. \& Fourie, A., 2011, 'Prospective agents for the biological control of Tithonia rotundifolia (Mill.) S.F. Blake and Tithonia diversifolia (Hemsl.) A. Gray (Asteraceae) in South Africa', African Entomology 19, 443-450. https:// A. Gray (Asteraceae) in South Afr
doi.org/10.4001/003.019.0223

Sinclair, A.R.E., Metzger, K.L., Mduma, S.A.R. \& Fryxell, J.M., 2015, Serengeti IV: Sustaining biodiversity in a coupled human-natural system, University of Chicago Press, Chicago, IL.

Soerohaldoko, S., 1971, 'On the occurrence of Eupatorium odoratum at the Game Reserve Penanjung, West Java, Indonesia', Weeds in Indonesia 2, 9.

Steenkamp, H.E. \& Chown, S.L., 1996, 'Influence of dense stands of an exotic tree, Prosopis glandulosa Benson, on a savanna dung beetle (Coleoptera: Scarabaeinae) assemblage in southern Africa', Biological Conservation 78, 305-311. https://doi. org/10.1016/S0006-3207(96)00047-X

Strathie, L.W., McConnachie, A.J. \& Retief, E., 2011, 'Initiation of biological control against Parthenium hysterophorus L. (Asteraceae) in South Africa', African Entomology 19, 378-392. https://doi.org/10.4001/003.019.0224

Tamado, T. \& Milberg, P., 2004, 'Control of parthenium (Parthenium hysterophorus) in grain sorghum (Sorghum bicolour) in the smallholder farming system in Eastern Ethiopia', Weed Technology 18, 100-105. https://doi.org/10.1614/WT-03-033R
Te Beest, M., Esler, K.J. \& Richardson, D.M., 2015a, 'Linking functional traits to impacts of invasive plant species: A case study', Plant Ecology 216(2), 293-305. https:// doi.org/10.1007/s11258-014-0437-5

Te Beest, M., Mpandza, N.J. \& Olff, H., 2015b, 'Fire and simulated herbivory have antagonistic effects on resistance of savanna grasslands to alien shrub invasion', Journal of Vegetation Science 26, 114-122. https://doi.org/10.1111/ jvs.12208

Towers, G.H.N. \& Mitchell, J.C., 1983, 'The current status of the weed Parthenium hysterophorus L as a cause of allergic contact dermatitis', Contact Dermatitis 9 , 465-469. https://doi.org/10.1111/j.1600-0536.1983.tb04465.x

Turner, P.J. \& Downey, P.O., 2010, 'Ensuring invasive alien plant management delivers biodiversity conservation: Insights from an assessment of Lantana camara in Australia', Plant Protection Quarterly, 25, 102-110.

Ueckert, D.N., Petersen, J.L., Potter, R.L., Whipple, J.D. \& Wagner, M.W., 1990, Range and sheep management for reducing pearmouth and other pricklypear-related health problems in sheep flocks, Texas Agricultural Experimental Station Program Report 4782, 40-41, Texas A\&M University, College Station, San Angelo, Texas, USA.

Urban, A.J., Simelane, D.O., Retief, E., Heystek, F., Williams, H.E. \& Madire, L.G., 2011 'The invasive "Lantana camara L." hybrid complex (Verbenaceae): A review of research into its identity and biological control in South Africa', African Entomology 19, 315-348. https://doi.org/10.4001/003.019.0225

Van der Hoeven, C.A. \& Prins, H.H.T., 2007, 'Invasive plant species threatens gorilla in equatorial Africa', PhD thesis, Department of Environmental Sciences, Resource Ecology Group, Wageningen University, Wageningen, the Netherlands.

Van der Laan, M., 2006, 'Allelopathic interference potential of the alien invader plant Parthenium hysterophorus L.', MSc thesis, University of Pretoria, South Africa.

Van Oosterhout, E., 2004, Lantana control manual: Current management and control options for lantana (Lantana camara) in Australia, Department of Natural Resources, Mines and Energy, Brisbane, Australia.

Van Wilgen, B.W. \& De Lange, W.D., 2011, 'The costs and benefits of biological control of invasive alien plants in South Africa', African Entomology 19, 504-514. https:// doi.org/10.4001/003.019.0228

Van Wilgen, B.W., Fill, J.M., Baard, J., Cheney, C., Forsyth, A.T. \& Kraaij, T., 2016, 'Historical costs and projected future scenarios for the management of invasive alien plants in protected areas in the Cape Floristic Region', Biological Conservation 200, 168-177.

Van Wilgen, B.W., Moran, V.C. \& Hoffmann, J.H., 2013, 'Some perspectives on the risks and benefits of biological control of invasive alien plants in the management of natural ecosystems', Environmental Management 52, 531-540. https://doi. org/10.1007/s00267-013-0099-4

Waterhouse, D.F., 1993, The major arthropod pests and weeds of agriculture in Southeast Asia: Distribution, importance and origin, Australian Centre for International Agricultural Research, Canberra, 141p.

Wells, M.J. \& Stirton, C.H., 1988, Lantana camara: A poisonous declared weed, Department of Agriculture and Water Supply, Pretoria, South Africa.

Winston, R.L., Schwarzländer, M., Hinz, H.L., Day, M.D., Cock, M.J.W. \& Julien, M.H., 2014, Biological Control of Weeds: A world catalogue of agents and their target weeds, 5th edn., USDA Forest Service, Forest Health Technology Enterprise Team, weeds, 5th edn., USD/
Morgantown, WV.

Wise, R.M., Van Wilgen, B.W. \& Le Maitre, D.C., 2012, 'Costs, benefits and management options for an invasive alien tree species: The case of mesquite in the Northern Cape', Journal of Arid Environments 84, 80-90. https://doi.org/10.1016/j. jaridenv.2012.03.001

Witkowski, E.T.F. \& Wilson, M., 2001, 'Changes in density, biomass, seed production and soil seed banks of the non-native invasive plant, Chromolaena odorata, alon a 15 year chronosequence', Plant Ecology 152(1), 13-27. https://doi.org/10. 1023/A:1011409004004

Witt, A.B.R., 2010, 'Biofuels and invasive species from an African perspective - A review', GCB Bioenergy 2, 321-329. https://doi.org/10.1111/j.1757-1707. 2010.01063.x

Yapi, T.S., 2014, 'An assessment of the impacts of invasive Australian wattle species on grazing provision and livestock production in South Africa', MSc thesis, Stellenbosch University, South Africa.

Zachariades, C., Hoffmann, J.H. \& Roberts, A.P., 2011a, 'Biological control of mesquite (Prosopis species) (Fabaceae) in South Africa', African Entomology 19, 402-415. https://doi.org/10.4001/003.019.0230

Zachariades, C., Strathie, L.W., Retief, E. \& Dube, N., 2011b, 'Progress towards the biological control of Chromolaena odorata (L.) R.M. King \& H. Rob. (Asteraceae) in South Africa', African Entomology 19, 282-302. https://doi.org/10.4001/ 003.019.0229 